\title{
Ownership Structure and Investor's Sentiments for Dividends
}

\author{
Elisabete Duarte Neves ${ }^{1}$ \\ ${ }^{1}$ Instituto Politécnico de Coimbra, ISCAC- Coimbra Business School, Quinta Agricola Bencanta, Coimbra, Portugal \\ Correspondence: Elisabete Duarte Neves, Instituto Politécnico de Coimbra, ISCAC- Coimbra Business School, \\ Quinta Agricola Bencanta, 3040-316, Coimbra, Portugal. E-mail: mneves@iscac.pt
}

Received: January 30, 2014

Accepted: February 15, $2014 \quad$ Online Published: March 30, 2014

doi:10.5430/ijfr.v5n2p35

URL: http://dx.doi.org/10.5430/ijfr.v5n2p35

\begin{abstract}
This paper is built upon the predictions of the catering theory of dividends and examines the interaction effect between catering incentives and corporate ownership structure in a behavioral context with catering effect. We intend to evaluate how the ownership structure affects the disposition of companies in Eurozone countries to adjust their payouts to the investors' sentiments. To achieve this aim, we propose a dividend model that incorporates a variable at a firm-level proxying for the catering effect. The results from the estimation of the model by using the GMM provide interesting results.

Our findings of the empirical analysis reveal an interaction effect between catering and ownership variables, particularly the level of managerial ownership and the interaction between the first and second largest shareholders, taking into account whether there is collusion or contestability between them.
\end{abstract}

Keywords: payout policy, catering, ownership structure

\section{Introduction}

Since the early 1980s a great number of papers have offered alternative explanations to disentangle the role played by corporate ownership structure in determining corporate dividend policy (see, for instance, Baker, Stein \& Wurgler, 2003). Dividends have been a bit of a puzzle in the theory of the firm since Miller and Modigliani (1961), and many scholars have tried to give alternative explanations for dividends in imperfect markets. In fact, existing research has had some success in explaining dividend payouts through a variety of market imperfections such as agency problems (see, for example, Easterbrook, 1984; Jensen, 1986; La Porta, Lopez -de- Silanes, Shleifer \& Vishny, 2000a; or Gugler, 2003), informational asymmetries (see, for example, Talmor, 1981; Miller \& Rock, 1985; Dewenter \& Warther, 1998; Baker, Stein \&Wurgler, 2003), and taxes (see, for example, Lasfer, 1996; Amihud \& Murgia, 1997; Bell \& Jenkinson, 2002; Rau \& Vermaelen, 2002; Oswald \& Young, 2004 or Morck \& Yeung, 2005). Our study asserts agency-cost explanations of corporate payout policy and behavioral considerations as a starting point for explaining the catering theory of dividends on different ownership structures across Eurozone countries. (Note 1)

According to agency theories, those who control the firm are tempted to do what is in their own best interests (Pinkowitz, Stulz \& Williamson, 2006, p. 2725). When corporate governance works well, managers are more likely to act in the interests of shareholders and pursue value-maximizing policies; that is, corporate decisions are made to increase shareholders' wealth. In contrast, with poor corporate governance, the dominant shareholder has greater ability to expropriate resources that would have been otherwise shared with minority owners; that is, he can obtain substantial private benefits from control at the expense of minority shareholders (see, for instance, Nenova, 2003; Dyck \& Zingales, 2004, Dahya, Dimitrov \& McConell, 2008). Several empirical studies have tried to determine the exact role played by ownership structures in the decision making process concerning corporate dividend policy. However, the evidence is mixed. (Note 2) The idea that dividends play a role in corporate governance is introduced by Easterbrook (1984) and Jensen (1986). Easterbrook (1984) argues that firms pay dividends to help reduce the agency costs associated with the separation of ownership and control. In fact, managers prefer to retain earnings to increase private consumption, because by paying dividends they must raise funds more frequently in the capital markets, where they are subjected to the scrutiny and the disciplining effects of the market. Jensen (1986) advocates a similar agency-theory argument, according to which dividend payments reduce free cash flow under insiders' discretion. (Note 3) Higher dividends achieve a cost-effective substitute to the shareholder. Rozeff (1982), Lang and Litzenberger (1989), Jensen, Solberg and Zorn (1992), and Agrawal and Jayaraman (1994) provide empirical support 
for these agency explanations for paying dividends. As point out by Fama and French (2001), the agency control function of corporate payout is linked to the severity of the manager-shareholder conflict. Jensen and Meckling (1976) and Shleifer and Vishny (1986), among others, identify the importance of agency problems in analyzing the ownership structure and value of corporations. One dimension of conflict in a corporate setting is the link between insiders (i.e., managers) and outside shareholders. Rozeff (1982) was among the first to explicitly recognize the role of insiders as one of monitoring the managers. Consistent with this view, the literature offers two competing hypotheses regarding this relationship: on one hand, managerial ownership can be used for the alignment of interests between managers and shareholders, however, the relationship between insiders and the alignment of shareholder and managerial interests may be non-monotonic, as suggested by Morck, Shleifer and Vishny (1988), Farinha (2003) or Pindado and de la Torre (2006). (Note 4) This close link is not a monotonous relationship, since it may combine a convergence effect at lower levels of managerial ownership with an entrenchment effect at higher levels of manager ownership. The role of large owners in the economy is also one of the most important topics in recent research on the relationship between dividends and ownership around the world. In fact, the divergence of interests of managers and owners can be reduced through the monitoring exerted by large shareholders (Shleifer\& Vishny, 1986; Jensen \& Murphy, 1990; Maug, 1998). In short, large owners may play a valuable role in reducing the original agency problem between shareholders and managers because a concentrated ownership solves the free-riding problem characterizing dispersed structures. The relevant consequence of financial discipline is that fewer resources are consumed in low return projects and more cash flows can thus be distributed as dividends. However, recent research has emphasized that large blockholdings give rise to a second agency problem between controlling owners and minority shareholders. (Note 5) In this case the relationships between large shareholders and dividend decisions cannot be positive because the expropriation hypothesis predicts that the high level of ownership concentration increases the propensity for expropriation of minority shareholders by large shareholders. As argued by Shleifer and Vishny (1997), when large shareholders gain nearly full control, they start generating private benefits of control that are not shared with minority shareholders. On the international front, La Porta et al. (2000a) provide a cross-country comparison from 33 countries and find that dividend differ consistent with a particular version of the agency theory of dividends. Specifically, they show that in Continental Europe where ownership structures are more likely to be concentrated, dividend payouts are generally lower and more flexible than in the Anglo-Saxon countries. (Note 6) However, despite the global importance of the European Union, (Note 7) very little published research has examined ownership structures and dividend payout across Europe. As far as we know, the most recent studies are single-country analyses, such as Crespi (1997) and Miguel, Pindado and de la Torre (2005) for Spain; Maury and Pajuste (2002) for Finland; Gugler (2003) for Austria; Gugler and Yurtoglu (2003) for Germany; Ginglinger and L'Her (2006) for France; and Renneboog and Szilagyi (2007) for the Netherlands, among others. (Note 8) Building on the agency framework developed by Jensen and Meckling (1976), a number of authors suggest that a higher equity ownership by controlling shareholders enhances their interest in non-distortionary distribution of dividends (Filatotchev, Kepelyushnikov, Dyomina \& Aukusionek 2001; La Porta et al., 2000a). (Note 9) When expropriation of private benefits of control involves costs, an increase in the size of the equity stake of a large block shareholder would reduce the marginal benefits of expropriation (see Bennedsen \& Wolfenzon, 2000; Claessens, Djankov, Joseph \& Lang 1999, for a discussion). Maury and Pajuste (2002) examine the relationship between controlling shareholders and dividend policy for Finnish listed firms, and they show that dividend payout ratio is negatively related to the control stake of the controlling shareholder. Their results suggest evidence for the existence of private benefits of control by strong blockholders. Moreover, Gugler and Yurtoglu (2003) argue that in countries characterized by high ownership concentration, the case of Eurozone countries in our study, the conflict between large and controlling owners and small outside shareholders is one of the main issues in corporate governance. An increase in dividends reduces the funds at the discretion of the controlling shareholder and increases the market value of the firm. A decrease in dividends potentially implies more severe rent extraction and expropriation of small shareholders. (Note 10) Concretely, they show for German firms that dividend payout ratios decrease in the equity share of the largest shareholder and report that lower dividend payout of majority controlled firms is related to the probability that controlling shareholders extract private benefits at the expense of minority shareholders; that is, an increase on dividends implies less cash available for expropriation and therefore a positive abnormal return. Overall, this prior research reveals that ownership structures impact firms' dividend decisions. Since the distribution of power within the company is reflected in a firm's dividend policies, we expected that the investors' perceptions of it impact payout ratio. In fact, recent developments in financial literature provide a new related theory of dividends, i.e., that dividend policy is related to catering towards investor demands (Baker \& Wurgler, 2004a). The propensity of firms to pay dividends seems to vary over time and these authors with their new explanation for dividends suggest that the time varying preferences of investors are the main driver behind this. According to this new theory, when investors' 
demand for payouts increases, firms are more likely to increase payouts. Recent studies (see, among others, Brown \& Cliff, 2004, 2005; Lai, 2004; Fairchild \& Zhang, 2005; Gemmil, 2005; Ferris, Sen \& Yui, 2006; Kumar \& Lee, 2006; Li \& Lie, 2006; Zhang, 2006; Denis \& Osobov, 2008; and Hoberg \& Prabhala, 2009) show that this new theory can be decisive in the resolution of the dividend puzzle through investors' sentiments. Furthermore, a related strand of the recent behavioral literature focuses directly on developing measures of sentiment and relating these to expected stock return (see, for instance, Brown \& Cliff, 2005; Baker \&Wurgler, 2006, 2007; Lemmon \& Portniaguina, 2006, or Qiu \& Welch, 2006). There is also literature, although much scarcer and conflicting, which refers to the importance of the ownership characteristics for a firm's payout. Richardson, Teoh and Wysocki (2001) find that earnings-guidance (a form of investor relations) is more prominent for firms whose insiders sell stocks from their personal accounts after earnings announcements; Ferris, Narayanan and Sanjiv (2008) show that catering is an important factor in explaining the differences in dividend policies across countries and find that measures of shareholder empowerment, such as the level of anti-director rights and the extent of equity ownership concentration, influence dividend catering.

Although there is no previous evidence, as far as we know, on what we are studying, there are strong arguments that lead us to argue that investors' preference for dividend-paying stocks change according to the above-mentioned ownership characteristics. Under the influence of this prior research, we go a step further and we investigate whether or not a firm's ownership characteristics moderate the extent to which firms cater to their investors' sentiments. In this piece of work we provide new empirical evidence by examining whether corporate ownership shapes the implications of this theory by determining managers' incentives to behave according to its predictions.

The remainder of this paper is organized as follows: In Section 2, we describe the main ownership characteristics that impact on dividend payout and summarize previous empirical evidence on this matter; we also report evidence on catering theory of dividends and how we posed our hypotheses. Section 3 describes the data and our model of dividends and discusses the estimation method. The results are discussed in Section 4 and, finally, the concluding remarks are presented in Section 5.

\section{Theories and Hypotheses}

In this section, we first summarize the main contributions from previous research to the debate on the impact of ownership structures on dividend payments for better understanding the ownership structure on the catering theory of dividends. We next discuss the key arguments of ownership structure on the catering theory of dividends and review previous evidence on the matter in order to pose our hypothesis. Note that to investigate this prediction empirically, and to get a step ahead of the intrinsic effect of investor sentiment, we start with a summary of the rises and falls of dividends payout with ownership characteristics, specifically managerial ownership, and ownership concentration.

\subsection{Managerial Ownership and Dividend Payout}

Several earlier studies have argued, from an agency perspective, that corporate payout is generally viewed as a control device that helps reduce managerial discretion, and as such, it is part of the firm's optimal monitoring. That is, the agency control function of dividend payout is linked to the severity of the manager-shareholder conflict. Rozeff (1982) reports that companies with more managerial participation pay fewer dividends. He shows that insider ownership provides direct incentives of alignment between managers and shareholders while dividends serve as a mechanism that reduces the managers' propensity to make unprofitable investments out of internal funds. The results of Lloyd, Jahera and Page (1985); Moh'd, Perry and Rimbey (1995), and Holder, Langrehr and Hexter (1998) also show this negative relationship between dividends and managerial ownership (Note 11).

In fact, there is extensive theoretical and empirical research on how managerial ownership influences dividend decisions. (Note 12) For instance, the signaling models for paying dividends, developed by Bhattacharya (1979), John and Williams (1985), and Miller and Rock (1985), suggest that managers as insiders choose dividend payment levels and dividend increases to signal private information to investors. The traditional agency theories, such as Jensen and Meckling (1976), Easterbrook (1984), and Jensen (1986), implicitly assume that any managerial entrenchment (more power to insiders) is undesirable because entrenched managers will always behave in ways that are costly to shareholder wealth. (Note 13) Jensen and Meckling (1976), for instance, suggest that managers have a natural tendency to allocate the firm's resources in their own best interests; hence the payment of dividends reduced the agency problem between manager and shareholder by reducing the discretionary funds available to managers. Managers may opt not to use the firm's resources in ways that increase shareholder returns, but squandering excess cash flow by investing in unprofitable projects, perquisites consumption, or other sort of value-destroying behavior. 
More recently, the evidence also suggests an inverse relation between managerial stock ownership and dividends. An increase in dividend payout will reduce the need for managerial ownership to control agency problems and it is expected that dividend payout ratio is inversely related to the level of managerial ownership. (Note 14) Gugler and Yurtoglu (2003) find a large negative effect of announced dividend changes in German companies where corporate insiders have more power.

In fact, if on one side managerial ownership can be used for the alignment of interests between managers and shareholders, on the other side, the augmentation of managerial ownership constitutes a means of empowerment of managers, giving them the opportunity to serve their personal interests, as it contributes to the reduction of the strict control imposed by shareholders; in other words, that is designated in the financial literature for management entrenchment hypothesis (see, for instance, Weston, 1979; Fama and Jensen, 1983 or Demsetz, 1983). (Note 15) As a result, dividend policy depends on the level of managerial ownership. In this vein of research, Schooley and Barney (1994) find a significant non-linear relationship between managerial ownership and dividends in US firms. Morck, Shleifer and Vishny (1988) argue that when managers control a substantial fraction of the firm's equity, the entrenched managers may be more inclined to consume perquisites. Also, Short, Zhang and Keasey (2002) and Farinha (2003) show a strong U-shaped relationship between dividend payouts and insider ownership for UK firms. In a similar fashion, as documented by Pindado and de la Torre (2006), insiders may offset their lower potential of shirking by increasing the amount of dividends they receive through share ownership. Those authors also find that initial increases in insider ownership result in a convergence of interests, while higher levels of insider ownership result in managerial entrenchment, showing a quadratic relation between dividends and insider ownership.

In fact, while the traditional agency theory suggests a uniformly negative relationship between managerial ownership and dividend payout ratio, the entrenchment theory proposes a non-monotonic relationship. (Note 16) Thanh and Heaney (2007) argue from 37 countries around the world that firms are less likely to pay dividends and pay fewer dividends when the largest shareholder is an insider, suggesting that powerful insiders may impose low dividend policies upon the firm in order to increase the cash flow at their discretion. Finally, as Morck, Shleifer and Vishny (1988) and Stulz (1988) find when examining the relation between firm value and managerial ownership, perhaps the two hypotheses (alignment of interests and managerial entrenchment) interact, each one dominating in different ownership levels. (Note 17) The relationship between dividends and managerial ownership may be positive across low levels of ownership, and this relationship could then turn out to be negative with higher levels of ownership.

Generally, as a result of previous literature, it is expected that for lower levels of managerial ownership, the ownership of shares by managers leads to the alignment of their interests with those of external shareholders, resulting in a high dividend payout ratio. For higher levels of managerial ownership, however, the ownership of shares by managers can lead to distortions in the operating decisions that they make, resulting in lower payout ratio.

\subsection{Ownership Concentration and Dividend Payout}

In most Eurozone countries, firms often have large controlling shareholders. Then, in firms with a concentrated ownership structure, a conflict of interest arises between large and small shareholders (Burkart, Gromb and Panunzi, 1997; La Porta et al., 1999). Controlling shareholders may be efficient monitors, but like managerial ownership, they may also keep payout levels low to expropriate minority shareholders.

As argued by Shleifer and Vishny (1997), large shareholders have a dual impact on firms, on one side, incentive to monitor management and on the other side, extract rents and enjoy private benefits of control. In the vein of these arguments, the literature offers two competing hypotheses regarding this relationship. On one side, the expropriation hypothesis predicts that the high level of ownership concentration increases the propensity for expropriation of minority shareholders by large shareholders and that controlling shareholders with substantial power adopt a policy that retains a larger amount of earnings that they can expropriate, resulting in lower payout. The substitution hypothesis is based on the assumption that firms need to raise external funds, and in order to sustain outside equity in the firm, the controlling shareholders establish a reputation for not expropriating wealth from minority shareholders by paying out more dividends. That is, the benefits of large shareholding can be summarized in terms of monitoring hypotheses. In agreement with these hypotheses, the largest shareholders make a basic paper in corporate governance by reducing agency costs. When a firm has free cash flows, managers cannot spend those amounts on unprofitable projects; they are forced to distribute these funds, resulting in higher dividend payouts. However, the presence of large shareholders with high stocks or controlling shareholders may be harmful to dividend payout. As discussed by Shleifer and Vishny (1997), when large shareholders have great control, they start generating private benefits of control that are not shared with minority shareholders. Then, the more important agency problem is expropriation of outside shareholders by the controlling shareholder (Kouki and Guizani, 2009). In fact, firms with large controlling 
shareholders may channel corporate resources to projects that generate utility for the controlling owners but provide few benefits to minority owners.

Based on the monitoring or expropriation hypotheses, there is much literature to show this relationship with the various financial decisions. Rozeff (1982) reports that companies with less dispersed ownership pay fewer dividends. Claessens, Djankov, Joseph and Lang. (2002), for instance, find stronger support for the view that firm value increases with cash-flow ownership of the largest shareholder. (Note 18)

In contrast, Shleifer and Vishny (1986) and Grossman and Hart (1980) argue in favor of a positive relationship between ownership concentration and dividends, leaning on the preference for the allotment of these largest shareholders, habitually companies, for tax reasons. (Note 19) As suggested by Faccio, Lang and Young (2001), the presence of multiple owners might alleviate expropriation of minority shareholders by the controlling shareholder. However, they find that the presence of multiple large shareholders helps to limit the expropriation of minority shareholders by controlling shareholders in European firms, but exacerbates agency problem in East Asian firms. This implies a negative rather than positive relationship between multiple owners and dividend payouts. (Note 20)

Maury and Pajuste (2002) examine the relationship between controlling shareholders and dividend policy for Finnish listed firms. They find that dividend payout ratio is negatively related to the control stake of the controlling shareholder. Moreover, their evidence supports the mitigating role of another large shareholder; they even report that the cumulative ownership of the three largest shareholders has a negative effect on dividend payout. They interpret this result as evidence for the existence of private benefits of control by strong shareholders.

Gugler and Yurtoglu (2003) analyze dividend announcements and dividend payout from German firms, focusing upon the large-small shareholder conflict. They present interesting results consistent with the rent extraction hypothesis. Their results show that the market reacts more negatively when large, uncontrolled shareholders reduce the dividends they are willing to pay out to minority shareholders. Gugler and Yurtoglu (2003) also report that payout levels decrease in the power of the largest shareholder but increase in the power of the second-largest shareholder. This evidence suggests on the one hand that, if the first shareholder is sufficiently powerful, it withholds dividends to expropriate minority investors for its private benefit; on the other hand, it points to a considerable monitoring function of large shareholders other than the largest shareholder.

Correia da Silva, Goergen and Renneboog (2005) report that dividends should be lower in the presence of a large controlling shareholder, because they need not constitute an additional control device and would lead to unnecessary liquidity constraints. Studies by Khan (2006) indicate a similar negative relationship between the largest shareholder and dividends from UK firms using a dynamic panel data. (Note 21) In contrast, Renneboog and Szilagyi (2007) report in Dutch firms that target payout ratios and the extent of dividend smoothing increase rather than decrease in the equity interest of the largest shareholder.

In general, the evidence is supportive of the hypothesis indicating that firms that have a strong controller tend to present lower payout ratios. This effect, for some authors, can be mitigated when there is a second block holder in the company.

\subsection{Ownership Structure and Dividend Policy on Catering Theory}

In the contemporary research concerning cross-section corporate governance, little has been said about the role which rapid fluctuations in investor sentiment can play in shaping corporate ownership structures. The dominant topic in the literature has traditionally been on legal matters. However, recent works provide evidence that investor sentiment has explanatory power for the cross-section of stock returns (see, for instance, Baker and Wurgler, 2006), and motivated by these findings, we go a step further and empirically investigate whether or not investors' preferences for dividend-paying stocks depend on the characteristics of corporate ownership. In this context, our study evaluates how the ownership structure affects the disposition of the firms to adjust their payouts to their investors' sentiments, establishing a relationship between the ownership structure and a proxy capturing investors' sentiments, which are built at firm level.

In fact, the explanation that has received the most recent attention, for being pioneering, is Baker and Wurgler's (2004a) catering theory. Consistent with their theory, those authors report empirical evidence that managers of U.S. firms attempt to cater to investor preferences and the aggregate dividend initiations are positively related to their measure of dividend premium. Baker and Wurgler (2004b) report that the dividend premium is related to the propensity to pay dividends, documented in Fama and French (2001). That is, these authors support the catering theory of dividends, which predicts that the time variation in dividends is driven by the demand from investors, according to which the changes in the amount that companies pay on dividends can be explained by what they 
denominate "catering incentives", that is, a measure of the market desire for dividend-paying stocks. Specifically, Baker and Wurgler (2004b) argue that while the dividend decision may be very important, it is even more important to base the direction of this decision on the prevailing investor sentiment. Previous literature on behavioral finance shows that investor sentiment does indeed influence future returns and plays a role in the formation of returns. (Note 22) For instance, De Long, Shleifer, Summers and Waldmann (1990) suggest that the limited arbitrage is formed by the irrational noise traders. According to their research, irrational traders affect market price much more than the arbitrageurs. This result forms a basic assumption in behavioral finance, which is called limitation of arbitrage. This alternative model can explain the divergence of asset price. Barberis, Shleifer and Vishny (1998) explain how individual investors underreact or overreact to past returns or fundamentals with a parsimonious model. More recently, Li and Lie (2006) extend the theory of Baker and Wurgler (2004a) and find support for the catering theory. They show that the dividend premium is positively related to the sign and magnitude of changes in dividends, and that this relationship is also manifested in the stock market reaction to these dividend changes. Their results suggest that the capital market rewards managers for considering investors' demand for dividends when making decisions about the level of dividends. A natural question that arises when attempting to quantify the influence of sentiment on dividends decisions is how to measure the unobserved sentiment. Theoretical and empirical literature have used different proxies of investors' sentiment. (Note 23) For instance, Lee, Shleifer and Thaler (1991) introduced one of the most popular financial measures, the closed-end fund discount, and Neal and Wheatley (1998) also used the same measure. Also consistent with behavioral models of investor overconfidence, Barber and Odean (2000) provide empirical evidence that households, which hold about half of U.S. equities, trade too much, on average. (Note 24) Wang (2003) presented a sentiment index which is based on current net positions and historical extreme values and find that funds with higher sentiment sensitivities (larger potential discounts) have a greater incentive to adopt a target distribution policy. Moreover, researchers exploit many quantities, such as mutual fund flows (Frazzini and Lamont, 2005, or Chiu, 2006); initial public offering volume and initial premium, and trading patterns of insiders. Schmitz, Glaser and Weber (2005) deduced a new measure for sentiment from individual investors' warrant transactions and reveal that returns have a negative influence on sentiment and the influence of stock market returns on sentiment is stronger than vice versa. Additionally, Bandopadhyaya and Jones (2006) suggest an equity market sentiment index which is based on the rank of daily return and the historical volatility. Baker and Wurgler (2006) built a sentiment composite index that is based on six proxies for sentiment. They show that investors' sentiment may have significant effects on the cross section of stock prices. Kumar and Lee (2006) suggest a sentiment measure, which is based on the retail investors' trading, and find that systematic retail explains return co-movement for stocks with high retail concentration. (Note 25) Baker and Wurgler (2007) show that the sentiment indicator is correlated in the expected way with the returns of portfolios sorted on volatility and also with the market. Finally, some studies use data from investor surveys, for instance, Brown and Cliff (2005), or Qiu and Welch (2006), (Note 26) and Kamstra, Kramer and Levi (2003) employ investor mood. (Note 27)

In fact, there are a growing number of studies that examine the role of investor sentiment and its implications for financial markets and institutions. Essentially, a surge in research for investor sentiment demands concerns to the "legal matters". However, in the contemporary discourse concerning the relationship between ownership structures and investors' sentiments legality seems ill-explored and no consensus exists. For instance, Barclay, Holderness and Pontiff (1993) find a stable and significant relationship between discounts and concentration of ownership. They speculate that block-holders might align with management to resist open-ending, and their results are more with managerial entrenchment than incentive (convergence of interest) effects. Hong and Huang (2005) find that insiders have a strong incentive to allocate resources to enhance the liquidity of their own block of stocks because of potential liquidity needs. In contrast, they show that dispersed shareholders care little about market illiquidity because of their relatively small holdings, leading to a divergence of interest on investor-relations policies. They show that liquidity needs and size of equity stakes are important determinants of the extent of investors' relations across firms. (Note 28) Ferris, Narayanan and Sanjiv (2008) show that catering is an important factor in explaining the differences in international decisions of dividend policy, and they show that catering is a much stronger phenomenon for firms operating in countries with low levels of ownership concentration and consequently, less ability to exploit their minority shareholders.

From the review above, we can say that previous literature offers several proxies for investors' sentiments, all of them at the market level. We propose a new empirical approach that allows us to measure investor sentiment at the firm level. Specifically, we use the error term of a valuation model to obtain a proxy for the catering effect on dividend payments (see Neves, Pindado \& de la Torre, 2006). 
There is no evidence, as far as we know, regarding ownership structure and the catering incentives for dividends. However, we use the argument offered in the previous sections to pose our hypotheses. These arguments point to the convergence of interests and entrenchment hypotheses with respect to the managerial ownership. Regarding the effect of ownership concentration on catering incentives, we rely on arguments pointing to monitoring versus expropriation effects. Finally, we go into this issue in-depth and investigate interaction between the first and second-largest shareholders, taking into account whether there is collusion or contestability between them.

Despite the lack of previous evidence, there are strong arguments that lead us to believe that investors' preference is for dividend-paying stocks changes in accordance with the above-mentioned ownership characteristics. Hong and Huang (2005), for instance, find that insiders have a strong incentive to allocate resources to enhance the liquidity of their own block of stocks because of potential liquidity needs. Ferris, Narayanan and Sanjiv (2008) are among the few authors that approach, although in a brief way, one of the pointed characteristics. They document that higher levels of ownership concentration would be associated with greater exploitation of minority shareholders; thus, if firms are generally characterized by high levels of ownership concentration, (Note 29) then in their results the payment of dividends should be associated with increased value and this would be reflected in a higher dividend premium level (their catering measure). However, those authors do not support this hypothesis and they find that, although catering occurs within firms irrespective of ownership concentration levels, the coefficient for the dividend premium is significantly greater for firms in countries with lower ownership concentration levels. They document that catering is a much stronger phenomenon for firms operating in countries with low levels of ownership concentration and consequently less ability to exploit their minority shareholders. This leads us to expect that for our analysis, an ownership concentration and its investor sentiment about dividends could be related. According to the finance literature that has analyzed the payout questions, and following our objective, we expect that different ownership structures affect the catering incentives to dividends payout. To test whether or not the ownership characteristics moderates this effect, we pose the following hypotheses:

Hypothesis 1: The higher the managerial ownership, the smaller the extents to which firms cater to their investors' sentiments.

Previous empirical evidence shows an unequivocal relation between managerial ownership and the firm's payout policy (see section 2.1), and despite the fact that none of these authors studied investors' sentiment on dividends, their work serves to justify our arguments and therefore this hypothesis. The arguments for this hypothesis are based in the convergence of interests or entrenchment effect (for instance, Morck, Shleifer \& Vishny, 1988). The incentive effect predicts that payout ratio will be higher when managers' interests are better aligned with small shareholders' interests. Therefore, a positive relation should exist between managerial ownership and catering incentives of dividends. On the other hand, the entrenchment effect predicts that a manager who controls substantial ownership may have enough voting power to determine policies which are beneficial to him at the expense of other shareholders. Jensen, Solberg and Zorn (1992), analyze the determinants of cross sectional differences in insider holdings and dividend policies of firms, and they find that if insider owners hold the major shares of the company then management naturally prefers not to pay dividends. This is consistent with Rozeff's model. Based on the above discussion, from higher level of managerial ownership, it is expected that investor preference for dividend-paying stocks manifests to a smaller extent.

To test the relationship between the ownership by the largest shareholder and catering incentives of dividends, we pose our second hypothesis:

Hypothesis 2: The higher the ownership by the largest shareholder, the smaller the extent to which firms cater to their investors' sentiments.

Once again the arguments that support our hypothesis are related to the literature that we showed previously based on the monitoring or expropriation effect. According to Grossman and Hart (1980) and Shleifer and Vishny (1986), management should be monitored, and this monitoring must be done by large shareholders. The presence of such shareholders mitigates the free rider problem of monitoring a management team and hence reducing the agency costs. According to the monitoring hypothesis, shareholders control managers' discretion, and they cannot expend free cash flow on unprofitable projects and are forced to pay dividends. On the contrary, when the conflict between large and small shareholders is more outstanding, as in the case of civil law countries, ownership by the largest shareholder favors a potential risk of expropriation. Shleifer and Vishny (1997) document that dominant shareholders derive private benefits from corporate resources under their control.

Accordingly, their preference is for lower dividend payments, which prevents minority investors from cashing out their share of the firm's profits. Our hypothesis is built under expropriation hypothesis (firms paying out less 
dividends when the controlling shareholders have substantial power to expropriate) because our sample is constituted fundamentally for civil law countries.

We rely on the intuition that the effect of the ownership by the largest shareholder on catering incentives should be according to the above theoretical arguments, i.e., monitoring and expropriation hypotheses. In fact, our hypothesis predicts that the stronger the control exerted by the first large shareholder, the lesser the extent to which the firm caters to the rest of investors' sentiments.

Financial literature also offer other factors in determining dividend payout, such as the influence of large shareholders other than the largest one, that may influence the alignment of interests or the expropriation of wealth between shareholders. Based on this view we pose the following hypothesis:

Hypothesis 3: The existence of a second large shareholder moderates the extent to which firms cater to their investors' sentiments.

In this line of research, Gugler and Yurtoglu (2003) suggest that controlling shareholders obtain private benefits from retaining resources inside the firms and refusing to satisfy the rest of shareholders' preference for dividends. Moreover, their results also indicate a considerable monitoring function of large shareholders other than the largest shareholder, that is, those authors point out a positive relation between the existence of a second shareholder and dividends. These results suggest that when investors perceive the existence of another shareholder who can moderate the control over the largest one, the demand for dividend payments may increase.

In firms with more than the first largest shareholder, these large shareholders interact and the second shareholder can contest the power of the first or collude with the same interests, i.e., the influence of a second shareholder is twofold, depending on whether there is contestability or collusion between them.

According to this double effect of a second large shareholder, we pose our last hypothesis:

Hypothesis 4: The joint effect of the first and second-largest shareholders on catering incentives will depend on whether there is contestability or collusion between them.

Faccio, Lang and Young (2001) report that dividend payouts are higher in Europe, but lower in Asia when there are multiple large shareholders. They find that the presence of multiple large shareholders dampens expropriation in Europe (due to monitoring), but exacerbates it in Asia (due to collusion).

Based on this assumption, Maury and Pajuste (2002) find that the negative effect of ownership concentration on dividends is not driven by the concentration of only the largest shareholder's voting power, but also the second largest shareholder's stake. These findings propose that the largest and second largest shareholders might collude in generating private benefits that are not shared with minority shareholders, as indicated by the lower dividend payout levels.

Maury and Pajuste (2005) document that on the one hand, by holding a substantial voting bloc, others besides the largest shareholder have the power and the incentives to monitor the largest shareholder and therefore the ability to reduce profit diversion. On the other hand, the second-largest shareholder can form a controlling coalition with other blockholders and share the diverted profit. Related to these arguments, those authors hypothesize that firm value is positively affected by the ability to challenge the largest bloc, i.e., by contestability, and negatively affected by the presence of blockholders, who, by colluding, can increase the efficiency of private benefit extraction.

Following this literature, we intended to corroborate our fourth hypothesis. In other words, we admitted that with another large shareholder, the intention of expropriating by the first can be contested and that is reflected positively in investors' demand for dividend paying stocks; that is, the catering incentives are larger when the investors perceive the good intention of the second shareholder.

\section{Data, Empirical Model and Estimation Method}

\subsection{Data}

To test the hypotheses posed in the previous section, we use data from several Eurozone countries. We selected an international database, Worldscope, as our principal source of information. (Note 30) Additionally, international data such as the growth of capital goods prices, the rate of interest on short-term debt, and the rate of interest on long-term debt, are extracted from the Main Economic Indicators published by the Organization for Economic Cooperation and Development (OECD).

Since our study is intended to present a wide variety of ownership characteristics, we selected Eurozone countries and for each country we constructed an unbalanced panel of non-financial companies from 1990 to 2003. For each country, 
we constructed an unbalanced panel of nonfinancial firms whose information is available for at least six consecutive years This strong requirement is a necessary condition since we lose one year of data in the construction of some variables, we lose another year of data because of the estimation of the model in first differences, and four-consecutive-year data is required in order to test for second-order serial correlation, as Arellano and Bond (1991) point out. We must test for second-order serial correlation because our estimation method, the GMM, is based on this assumption. Three of the twelve countries have been excluded from our analysis for various reasons. As occurs in La Porta et al. (2000b), Luxembourg has been removed from our sample because there are just a few firms listed in Luxembourg's stock exchange, and Greece because dividends are mandatory in this country. Finally, the Netherlands also had to be excluded because no sample with the above-mentioned ownership factors could be selected. The structure of the samples by number of companies and number of observations per country is provided in Table 1. As shown in Table 2, the resultant unbalanced panel comprises 487 companies and 4,535 observations.

Table 1. Structure of the samples by countries

\begin{tabular}{ccccc}
\hline Country & $\begin{array}{c}\text { Number of } \\
\text { companies }\end{array}$ & $\begin{array}{c}\text { Percentage of } \\
\text { companies }\end{array}$ & $\begin{array}{c}\text { Number of } \\
\text { observations }\end{array}$ & $\begin{array}{c}\text { Percentage of } \\
\text { observations }\end{array}$ \\
\hline Germany & 91 & 18.69 & 885 & 19.51 \\
France & 79 & 16.22 & 721 & 15.90 \\
Belgium & 67 & 13.76 & 693 & 15.28 \\
Spain & 62 & 12.73 & 603 & 13.30 \\
Finland & 60 & 12.32 & 528 & 11.64 \\
Portugal & 44 & 9.03 & 362 & 7.98 \\
Ireland & 39 & 8.01 & 394 & 8.69 \\
Austria & 31 & 6.37 & 241 & 5.31 \\
Italy & 14 & 2.87 & 108 & 2.38 \\
\hline Total & 487 & 100.00 & 4,535 & 100.00 \\
\hline
\end{tabular}

The table shows extracted data from firms for which information is available for at least five consecutive years between 1990 and 2003. After removing the first-year data, used only to construct several variables, the resultant samples comprise 91 firms (885 observations) for Germany, 79 firms (721 observations) for France, 67 firms (693 observations) for the Belgium, 62 firms (603 observations) for Spain, 60 firms (528 observations) for Finland, 44 firms (362 observations) for Portugal, 39 firms (394 observations) for Ireland, 31 firms (241 observations) for Austria and 14 firms (108 observations) for Italy.

Table 2. Structure of the panel

\begin{tabular}{ccccc}
\hline $\begin{array}{c}\text { No. of annual } \\
\text { observations } \\
\text { per company }\end{array}$ & $\begin{array}{c}\text { Number of } \\
\text { companies }\end{array}$ & $\begin{array}{c}\text { Percentage of } \\
\text { companies }\end{array}$ & $\begin{array}{c}\text { Number of } \\
\text { observations }\end{array}$ & $\begin{array}{c}\text { Percentage of } \\
\text { observations }\end{array}$ \\
\hline $\mathbf{1 3}$ & 96 & 19.71 & 1,248 & 27.52 \\
$\mathbf{1 2}$ & 50 & 10.27 & 600 & 13.23 \\
$\mathbf{1 1}$ & 40 & 8.21 & 440 & 9.70 \\
$\mathbf{1 0}$ & 39 & 8.01 & 390 & 8.60 \\
$\mathbf{9}$ & 53 & 10.88 & 477 & 10.52 \\
$\boldsymbol{8}$ & 59 & 12.11 & 472 & 10.41 \\
$\mathbf{7}$ & 50 & 10.27 & 350 & 7.72 \\
$\mathbf{6}$ & 58 & 11.91 & 348 & 7.67 \\
$\mathbf{5}$ & 42 & 8.62 & 210 & 4.63 \\
\hline Total & 487 & 100.00 & 4,535 & 100.0 \\
\hline
\end{tabular}

Data from firms for which information is available for at least five consecutive years between 1990 and 2003 were extracted. After removing first-year data, used only to construct several variables, the resultant unbalanced panel comprises 487 firms (4,535 observations).

Finally, Table 3 provides summary statistics (mean, standard deviation, minimum and maximum) of the variables used in our analysis. 
Table 3. Summary statistics

\begin{tabular}{|c|c|c|c|c|}
\hline Variable & Mean & $\begin{array}{l}\text { Standard } \\
\text { deviation }\end{array}$ & Minimum & Maximum \\
\hline$F C F_{i t}$ & .04878 & .11942 & -1.6551 & 1.2737 \\
\hline$D_{i t}$ & .10835 & .12269 & .0000 & .83362 \\
\hline$N I_{i t}$ & .02696 & .06346 & -.78456 & .65152 \\
\hline$T A N G_{i t}$ & .43242 & .18674 & .00006 & .98799 \\
\hline$S I_{i t}$ & 12.6767 & 1.6982 & 7.7376 & 18.4956 \\
\hline$C A T_{i t}$ & .0000 & .64772 & -2.9818 & 8.0215 \\
\hline
\end{tabular}

The table provides summary statistics (mean, standard deviation, minimum, and maximum) of the variables used in the construction of the explanatory variables. $D_{i t}$ represents debt ratio, $F C F_{i t}$ is the free cash flow, $N I_{i t}$ denotes net income, $T A N G_{i t}$ denotes tangible fixed assets, $S I_{i t}$ is size, and $C A T_{i t}$ denotes catering variable, constructed according to the second chapter.

\subsection{Empirical Model and Estimation Method}

Using the dependent variable, payout ratio, obtained as explained in Neves, Pindado and de la Torre (2006) (Note 31 ), and the traditional explanatory variables as well as the catering variable obtained through the value model (explained in the same paper), we next present our models. In accordance with the aim of our study, we investigate whether or not several ownership characteristics impact the catering effect of dividends on firms across Eurozone countries, and for that we propose the following models to be estimated:

$$
C P R_{i t}=\gamma_{0}+\gamma_{1} F C F_{i t}+\gamma_{2} D_{i t}+\gamma_{3} N I_{i t}+\gamma_{4} T A N G_{i t}+\gamma_{5} S I Z E_{i t}+C A T_{i t}\left(\gamma_{6}+\lambda D V_{i t}\right)+\varepsilon_{i t} \text {, }
$$

where $D V_{i t}$ takes value 1 if the firm's level of managerial ownership is above the sample median, and 0 otherwise. In this way, the coefficient of the catering variable is $\gamma_{6}$ for firms with low levels of insider ownership (since $D V_{i t}$ takes value zero), and $\gamma_{6}+\lambda$ for firms with high levels of insider ownership (since $D V_{i t}$ takes value one).

In this first model we investigate the interaction between the catering effect and the level of managerial ownership, to evaluate the moderating role of managerial ownership on catering dividends, where, $D V_{i t}$ is a dummy variable constructed according to the level of managerial ownership. It is worth noting that in all cases whenever the dummy variable equals one and both parameters $\left(\gamma_{6}\right.$ and $\left.\lambda\right)$ are significant, a linear restriction test is needed in order to know whether their sum $\left(\gamma_{6}+\lambda\right)$ is significantly different from zero. The null hypothesis to be tested in these cases is the hypothesis of no significance, $H_{0}: \gamma_{6}+\lambda=0$. We also investigate whether the ownership concentration in the hands of the first shareholder moderates the catering effect, by estimating the following model:

$$
C P R_{i t}=\gamma_{0}+\gamma_{1} F C F_{i t}+\gamma_{2} D_{i t}+\gamma_{3} N I_{i t}+\gamma_{4} T A N G_{i t}+\gamma_{5} S I Z E_{i t}+C A T_{i t}\left(\gamma_{6}+\lambda D V_{i t}\right)+\varepsilon_{i t} \text {, }
$$

where $D V_{i t}$ is a dummy variable constructed according to the level of ownership concentration by largest shareholder. In this model, $D V_{i t}$ takes value 1 if the firm's level of equity ownership concentration by the largest shareholder is above the sample mean, and 0 otherwise. (Note 32) For testing the interaction between the first and second-largest shareholders with catering incentives, we propose the model that follows:

$$
C P R_{i t}=\gamma_{0}+\gamma_{1} F C F_{i t}+\gamma_{2} D_{i t}+\gamma_{3} N I_{i t}+\gamma_{4} T A N G_{i t}+\gamma_{5} S I Z E_{i t}+C A T_{i t}\left(\gamma_{6}+\lambda_{6} D V_{i t}+\alpha_{6} S V_{i t}\right)+\varepsilon_{i t} \text {, }
$$

where $D V_{i t}$ is a dummy variable constructed according to the level of ownership concentration of the largest shareholder and $S V_{i t}$ is a dummy variable constructed according to the existence (with equity stock) of the second shareholder. In this case, $D V_{i t}$ takes value 1 if the firm's level of equity ownership concentration by the largest shareholder is above the sample mean, and 0 otherwise. $\mathrm{S} V_{i t}$ takes value 1 if the second shareholder has equity stocks, and 0 otherwise. In this way, the coefficient of the catering variable is $\gamma_{6}$ for firms with low levels of equity shares by the largest shareholder and at the same time for firms where the second shareholder doesn't exist (since $D V_{i t}$ and $\mathrm{S} V_{i t}$ takes value zero). The coefficient is $\gamma_{6}+\lambda_{6}$ for firms with high levels of equity ownership by the largest shareholder and at the same time the second shareholder doesn't have equity shares (since $D V_{i t}$ takes value one and $\mathrm{S} V_{i t}$ takes value zero). The coefficient is $\gamma_{6}+\alpha_{6}$ for firms with low levels of equity ownership by the largest shareholder and at the same time the second shareholder exists (since $D V_{i t}$ takes value zero and $\mathrm{S} V_{i t}$ takes value one). The coefficient 
is $\gamma_{6}+\lambda_{6}+\alpha_{6}$ for firms with high levels of equity ownership by the largest shareholder and at the same time the second shareholder exists (since $D V_{i t}$ and $\mathrm{S} V_{i t}$ takes value one). Finally, we investigate whether the joint effect of largest shareholder and the contestability or collusion of the second shareholder moderate catering effect and we estimate the following model:

$$
C P R_{i t}=\gamma_{0}+\gamma_{1} F C F_{i t}+\gamma_{2} D_{i t}+\gamma_{3} N I_{i t}+\gamma_{4} T A N G_{i t}+\gamma_{5} S I Z E_{i t}+C A T_{i t}\left(\gamma_{6}+\lambda_{6} D V_{i t}+\alpha_{6} C V_{i t}\right)+\varepsilon_{i t},
$$

where $D V_{i t}$ is the same dummy variable constructed according to the level of ownership concentration of the largest shareholder and $C V_{i t}$ is a dummy variable constructed according to the contestability or collusion of the second shareholder relative to the first. In this case, $D V_{i t}$ takes value 1 if the firm's level of equity ownership concentration by the largest shareholder is above the sample mean, and 0 otherwise. $\mathrm{C} V_{i t}$ takes value 1 if there is contestability of the second shareholder and 0 if there is collusion. (Note 33) This dummy variable was constructed based on Maury and Pajuste (2005). On the one hand, by holding a substantial equity share, a second shareholder has the power and the incentives to monitor the largest shareholder and therefore the ability to challenge the largest block, i.e., by contestability. On the other hand, the second shareholder can form a controlling coalition with the first shareholder and share the diverted profit; in this case, by colluding, the presence of these two block holders, can increase the efficiency of private benefit extraction. Our models are estimated by the panel data methodology. Two issues are considered in making this choice. First, unlike cross-sectional analysis, panel data allow us to control for individual heterogeneity. This point is crucial in our study because the dividend decision is very closely related to the specificity of each firm. In fact, each firm has a different propensity to pay dividends, which could be regarded as unobserved heterogeneity. Therefore, to eliminate the risk of obtaining biased results, we control for such heterogeneity by modeling it as an individual effect, $\eta_{\mathrm{I}}$, which is then eliminated by taking first differences of the variables. Consequently, the error term in our models, $\varepsilon_{i t}$, is split into four components: first, the above-mentioned individual or firm-specific effect, $\eta_{\mathrm{i}}$. Second, $d_{t}$ measures the time-specific effect by the corresponding time dummy variables, so that we can control for the effects of macroeconomic variables on the dividend decision. Third, since our models are estimated using data from several countries, we also include country dummy variables $\left(c_{i}\right)$. Finally, $v_{i t}$ represents the random disturbance. The second issue we address by using the panel data methodology is the endogeneity problem. The endogeneity problem is likely to arise insofar as the dependent variable (payout ratio) explains some explanatory variables. For instance, the payout ratio may explain leverage on the basis of arguments used to justify reverse causality (e.g. Moh'd, Perry, \& Rimbey 1995, 1998). Finally, we check for potential misspecification of the models. First, we use the Hansen $\mathbf{J}$ statistic of over-identifying restrictions in order to test for the absence of correlation between the instruments and the error term. Tables 4 and 5 show that the instruments used are valid. Second, we use the $m_{2}$ statistic, developed by Arellano and Bond (1991), in order to test for lack of second-order serial correlation in the first-difference residual. Tables 4 and 5show that there is no problem of second-order serial correlation in our models (see $m_{2}$ ). Note that although there is first-order serial correlation (see $m_{l}$ ), this is caused by the first-difference transformation of the model and, consequently, it does not represent a specification problem of the models. Third, the results shown in Tables 4 and 5 provide good outcomes for the following three Wald tests: $z_{1}$ is a test of the joint significance of the reported coefficients; $z_{2}$ is a test of the joint significance of the time dummies; and $z_{3}$ is a test of the joint significance of the country dummies.

\section{Results}

\subsection{The Moderating Role of Ownership Variables}

In this section we present the results of our models by incorporating a variable capturing investor sentiment, the catering variable, for testing the implications of the catering theory by means of several ownership characteristics, four in particular: the level of managerial ownership, the equity stocks in the hands of the first shareholder, the presence of the second shareholder and the effect of contestability or collusion by this second shareholder relative to the first. 
It is worth noting that, as far as we know, there is no prior evidence supporting this view, and providing empirical support for this issue is thus one of the major contributions of this research.

Column I of Table 4 reports the results of the model that includes the interaction of the catering variable with managerial ownership. (Note 34) As shown in the table, for firms with low levels of managerial ownership there is a positive effect from a firm's investor sentiment on its payout ratio $\left(\gamma_{6}=0.00121\right.$, significantly different from zero; see t). However, the effect turns negative for firms with high levels of managerial ownership $\left(\gamma_{6}+\lambda=-0.00259\right.$, significantly different from zero; see $\mathrm{t}$ ). That is, our evidence suggests that investor demand for dividends translates into higher payout ratios only in those firms with low levels of managerial ownership, whereas firms with high levels of insiders do not seem to cater to investor preferences. This suggests that receipt of dividends is more important to investors when managers don't have greater ability to expropriate corporate earnings for their private benefit. Consistent with Hypothesis 1, this result corroborates that the higher the managerial ownership, the smaller the extents to which firms cater to their investors' sentiments. This idea supports, for instance, the key arguments by Rozeff (1982), or Moh'd, Perry and Rimbey (1995), who report that firms with more managerial ownership pay fewer dividends. Our results suggest the entrenchment effect that predicts that a manager who controls substantial ownership may determine policies which are beneficial to him at the expenses of other shareholders, resulting in lower payouts (Jensen, Solberg \& Zorn, 1992). Also, Morck, Shleifer and Vishny (1988) observe that at sufficiently high levels of stock ownership, managerial entrenchment may dominate the positive incentive effects of more direct alignment (see section 2.1).

The interaction of the catering effect with the variable capturing the ownership in the hands of the largest shareholder is tested in the model presented in Column II of Table 4. As shown in the table, the catering effect is positive in firms with low levels of equity concentration by the largest shareholder $(\gamma 6=0.00914)$, whereas this effect turns negative for firms with high levels of equity ownership concentration in the hands of the largest shareholder $(\gamma 6+\lambda=-0.00185$, significantly different from zero; see t). Our evidence supports Hypothesis 2, according to which majority controlled firms by the first-largest shareholder cater to a smaller extent to their investors' sentiments. Correia da Silva, Goergen and Renneboog (2005) find that, given that strong shareholders exert their control power, there is no need for the dividend policy to constitute an additional monitoring device. We interpret these findings as further evidence of agency conflicts between largest shareholders and minority investors, as for instance, Thomsen (2005). Therefore, it seems that catering incentives (i.e., investor preference for dividend-paying stocks) manifest more strongly in firms with low levels of ownership in the hands of the largest shareholder. This result intuitively supports traditional arguments by Rozeff (1982), who argues that companies with less dispersed ownership pay fewer dividends. Our evidence suggests that the dominant shareholder has the power to divert corporate resources to himself from other shareholders and that translates into investors' smaller incentives for dividends who perceive expropriation power by majority controlled firms. Our evidence is also consistent with Maury and Pajuste (2002) and Gugler and Yurtoglu (2003), and suggests that controlling shareholders obtain private benefits from retaining resources inside the firms and refusing to satisfy the rest of shareholders' preference for dividends. As expected, the positive effect predicted by Ferris, Narayanan and Sanjiv (2008) is confirmed by our results (see section 2.2).

Table 4. Estimation results of the moderating role of managerial ownership and ownership concentration in the hands of the largest shareholder

\begin{tabular}{lcc}
\hline & $\mathrm{I}$ & $\mathrm{II}$ \\
\hline Constant & $-.0263^{*}(.00074)$ & $-.02969^{*}(.00064)$ \\
$F C F_{i t}$ & $.00537^{*}(.00023)$ & $.00863^{*}(.00022)$ \\
$D_{i t}$ & $.01097^{*}(.00032)$ & $.01608^{*}(.00038)$ \\
$N I_{i t}$ & $.14767^{*}(.00040)$ & $.02017^{*}(.00047)$ \\
$T A N G_{i t}$ & $.00665^{*}(.00023)$ & $.01142^{*}(.00027)$ \\
$S_{i t}$ & $.00178^{*}(.00006)$ & $.00186^{*}(.00044)$ \\
$C A T_{i t}$ & $.00121^{*}(.00005)$ & $.00914^{*}(.00014)$ \\
$C A T_{i t} D V_{i t}$ & $-.00380^{*}(.00012)$ & $-.01099^{*}(.00018)$ \\
$t$ & -30.57 & -25.97 \\
$z_{1}$ & $323.89(7)$ & $684.53(7)$ \\
$z_{2}$ & $10735.26(11)$ & $23577.50(11)$ \\
$z_{3}$ & $90.10(6)$ & $130.37(6)$ \\
$m_{1}$ & 0.08 & -0.03 \\
$m_{2}$ & -1.24 & -1.03 \\
Hansen & $347.25(392)$ & $391.75(392)$ \\
\hline
\end{tabular}


The regressions are performed using the panel described in Table 4. $D V_{i t}$ is a dummy variable that takes the following values: a) 1 if the level of managerial ownership is above the sample median and 0 otherwise in Column I; b) 1 if the ownership by the largest shareholder is above the sample mean and 0 otherwise in Column II.The remainder of the information needed to read this table is as follows: i) Heteroscedasticity consistent asymptotic standard error in parentheses. ii) *,**, and *** indicate significance at the $1 \%, 5 \%$, and $10 \%$ levels, respectively; iii) tis the t-statistic for the linear restriction test under the null hypothesis of no significance; iv) $z_{1}, z_{2}$ and $z_{3}$ are Wald tests of the joint significance of the reported coefficients, of the time dummies, and of the country dummies, respectively, asymptotically distributed as $\chi^{2}$ under the null of no significance, with degrees of freedom in parentheses; $\left.v\right) m_{i}$ is a serial correlation test of order $\mathrm{i}$ using residuals in first differences, asymptotically distributed as $\mathrm{N}(0,1)$ under the null of no serial correlation; vi) Hansen is a test of the over-identifying restrictions, asymptotically distributed as $\chi^{2}$ under the null of no correlation between the instruments and the error term, degrees of freedom in parentheses.

In addition to the largest controlling shareholders, we also tested whether the presence of other large shareholders has influence on catering incentives of dividend policy.

For testing the joint effect of the first and second-largest shareholders on catering incentives, we propose the model presented in Column I of Table 5. As shown in the table, firms with low levels of ownership by the largest shareholder and no second-largest shareholders exhibit a positive catering effect $(\gamma 6=0.00943)$. Our evidence suggests that in firms without a second shareholder, but where the largest shareholder doesn't have the power to control, managers are more encouraged to cater to a large extent to investors' demand for dividends, confirming once more that just for high level of ownership the largest shareholder has the power to divert corporate resources to himself from other shareholders, resulting in smaller catering incentives to dividends (results corroborated by hypothesis 2). In this way, our results suggest that in firms with lower levels of ownership by the largest shareholder, dividend payments are a substitute monitoring device. The catering effect is also positive and larger in firms in which the largest shareholder has a majority stake but there is also a second large shareholder $(\gamma 6+\lambda 6+6 \alpha=0.02645$, significantly different from zero; see $t 2$ ).

This result confirms that a second large shareholder has incentives to control and monitor the largest shareholder. Under pressure, the controlling shareholder is generally expected to pay out more. Thus, the monitoring exerted by other large shareholders makes dividends more likely. In other words, when there is a second large shareholder in the firm, investors perceive that the largest one cannot so easily expropriate their wealth, because the firm caters to a larger extent to their sentiment and higher dividends are paid.

For instance, Gugler and Yurtoglu (2003) document that the power of the second-largest shareholder increases the payout. The second shareholder plays a critical role in contesting the control of the dominant largest shareholder in order to reduce the extraction of private benefits and improve the firm's payout ratios. More interestingly, the catering effect is even more relevant when the level of equity in hands of the largest shareholder is low and there is a second large shareholder in the firm $(\gamma 6+6 \alpha=0.03918$ significantly different from zero, see $t 2)$.

Financial literature shows that ownership concentration facilitates the expropriation of wealth from the small shareholders by the largest shareholders. However, our evidence points out that if the first shareholder doesn't have power to control, the existence of other large shareholders comes to reinforce the increase of the investors' incentives for dividends, because in those companies there are no reasons to believe that the minority shareholders can be expropriated.

Finally, the catering effect turns negative when the largest shareholder has a majority stake that confers on him the power to control the company and there is no second large shareholder in the firm $(\gamma 6+\lambda 6=-0.0033$, significantly different from zero, see $t 1$ ). This result clearly manifests for expropriation reasons, that is, when the largest shareholder has the power to control, and the second shareholder is not present to contest the control of the dominant largest shareholder in order to reduce the extraction of private benefits and improve the firm's dividend decisions, the first shareholder expropriates the minority's interests.

These results point out that catering incentives clearly manifest themselves when there are no shareholders large enough to control the firm and the dividend decision, or when there is a second large shareholder in the company. This evidence confirms Hypothesis 3 regarding the role played by a second large shareholder, jointly considered with the stake of the largest shareholder, in moderating the catering effect. Additionally, our results suggest that the presence of a second large, non-controlling shareholder in the firm enhances the monitoring of largest shareholders' opportunism. In this line, Gugler and Yurtoglu (2003) show that firms that have a strong controller tend to present lower payout ratios, but this effect is mitigated when there is a second block holder in the company (see section 2.2). 
Finally, the influence of a second reference shareholder can be twofold: on one hand, the second shareholder can form a controlling coalition with the largest shareholder to share diverted profit; that is, controlling owners are encouraged to expropriate the remaining shareholders, and, hence, to reduce the firm's payout. But on the other hand, the second shareholder has incentives to monitor the largest shareholder; that is, it is possible that the other major shareholders take actions to avoid the expropriation by the larger major shareholders. This effect is called contestability by Maury and Pajuste (2005).

Therefore, we introduce the contestability and collusion effect into our analysis. We investigate whether the joint effect of the first and second largest shareholders on catering incentives depends on whether there is contestability or collusion between them. With this aim, we estimate the model presented in Column II of the Table 5. As shown in the table, firms in which the largest shareholder has a low stake and colludes with the second large shareholder exhibit a positive catering effect $(\gamma 6=0.00967)$. This finding suggests that if the first and second large shareholders have a low level of ownership concentration, there is no possibility nor ability to expropriate: that means both prevail in catering theory. The catering effect is positive and stronger when the largest shareholder has a majority stake but there is also a second large shareholder that contests the decisions taken by the former. $(\gamma 6+\lambda 6+6 \alpha=0.34798$, significantly different from zero; see $t 2$ and $t 1$ ).

As reported by Maury and Pajuste $(2002,2005)$, when second shareholder has a substantial voting bloc, he also has the power and the incentive to monitor the largest shareholder and therefore the ability to reduce profit diversion and in this case, the ability of large shareholders to contest the largest shareholder should be encouraged.

Accordingly, our results suggest that the contestability of the second shareholder leads to power to limit the expropriation of minority shareholders, resulting in higher catering incentives for dividends.

Once more, the results are still interesting for firms with low levels of equity shares in the hands of the largest shareholder and when the second shareholder has the power to contest $(\gamma 6+6 \alpha=0.36022$ significantly different from zero; see $t 2$ ). We find that when the largest shareholder doesn't have power to control, the contestability of the other large shareholder comes to reinforce the increase of the investors' incentives for dividends, because in those companies there are no reasons to believe that the minority shareholders can be expropriated. Even if it is possible, the second shareholder would have power to contest acting as an effective monitor.

These results corroborate the previous evidence that we had already shown in the model (3) with the presence of a second shareholder. Column II of the Table 5, our model (4), also shows that the catering effect turns negative when the largest shareholder has the power to control the decision-making in the company and, additionally, there is collusion with the second large shareholder $(\gamma 6+\lambda 6=-0.00257$, significantly different from zero; see $t 1)$. Therefore, by colluding, the presence of these two blockholders can increase the efficiency of private benefit extraction and it seems that catering incentives (i.e., investors' preference for dividend-paying stocks) lose priority in the firm (see Maury and Pajuste, 2002).

Our evidence suggests that in firms with the power of contestability of the second shareholder, and in the situation that the first shareholder does not have controlling power, management is more encouraged to cater to the firm's investors' demand for dividends. As in Gugler and Yurtoglu (2003), this result is consistent with the argument that strong minority shareholders demand dividends to avoid being expropriated by the main incumbent shareholder.

Table 5. Estimation results of the moderating role of ownership concentration in the hands of the largest shareholder and the existence or contestability of second largest shareholder

\begin{tabular}{lcc}
\hline & $\mathrm{I}$ & $\mathrm{II}$ \\
\hline Constant & $-.02746^{*}(.00056)$ & $-.01734^{*}(.00050)$ \\
$F C F_{i t}$ & $.00885^{*}(.00020)$ & $.01194^{*}(.00030)$ \\
$D_{i t}$ & $.01885^{*}(.00037)$ & $.01713^{*}(.00038)$ \\
$N I_{i t}$ & $.02068^{*}(.00040)$ & $.01708^{*}(.00040)$ \\
$T A N G_{i t}$ & $.00779^{*}(.00030)$ & $.00777^{*}(.00029)$ \\
$S_{i t}$ & $.00183^{*}(.00004)$ & $.00106^{*}(.00004)$ \\
$C A T_{i t}$ & $.00943^{*}(.00012)$ & $.00967^{*}(.00019)$ \\
$C A T_{i t} D V_{i t}$ & $-.01273^{*}(.00018)$ & $-.01224^{*}(.00023)$ \\
$C A T_{i t} S V_{i t}$ & $.02975^{*}(.00121)$ & \\
$C A T_{i t} C V_{i t}$ & & $.35055^{*}(.01776)$ \\
$t l$ & -36.32 & -30.73 \\
$t_{2}$ & 31.32 & 20.21
\end{tabular}




\begin{tabular}{lcc}
$z_{1}$ & $840.57(8)$ & $420.21(8)$ \\
$z_{2}$ & $16212.29(11)$ & $15061.86(11)$ \\
$z_{3}$ & $131.29(6)$ & $150.63(6)$ \\
$m_{1}$ & -0.08 & -0.12 \\
$m_{2}$ & -0.96 & -0.87 \\
Hansen & $397.00(391)$ & $382.10(391)$ \\
\hline
\end{tabular}

The regressions are performed using the panel described in Table 5. $D V_{i t}$ is a dummy variable that takes the following values: a) 1 if the ownership concentration by the largest shareholder is above the sample mean and 0 otherwise in Column I; b) $S V_{i t}$ is a dummy variable that takes value 1 if a second large shareholder exists and 0 otherwise in Column I; c) $C V_{i t}$ is a dummy variable that takes value 1 if there is contestability between the first and second largest shareholders and 0 if there is collusion between them in column II.

\section{Conclusions}

This study is built upon the predictions of the catering theory of dividends, and contributes to the somewhat sparse empirical literature towards understanding the implications of catering incentives for dividend policies by examining the moderating role played by certain ownership variables, using a sample of large quoted firms in Eurozone member countries. In fact, our research makes a further check to see which ownership variables moderate dividend payout to managers' action to cater. This idea has not been accounted for in previous studies, either theoretically or empirically, but our findings corroborate that the way in which investors appreciate dividend payments and the incentives of the companies to satisfy these desires depends on the firm's degree of managerial ownership, ownership concentration by largest shareholder, the presence of a second shareholder, and finally, with the possibility of contestability or collusion between the largest and second-largest shareholders. The results of the empirical analysis reveal, in first place, that investor preference for dividend-paying stocks translates into lower payout ratios in those firms with high levels of managerial ownership. Second, investor sentiment negatively impacts the payout ratio of only those firms with a high degree of equity shares in the hands of the first shareholder, for which investors manifest weaker expectations about receiving higher dividends. Further, we find that for high degree of ownership concentration by the largest shareholder jointly with the presence of a second shareholder, investor sentiment positively impacts the payout ratio. More interesting, our evidence shows that the catering effect persists and is more evident when the first shareholder does not have the power to control the company and the second shareholder has equity shares. Once more, our evidence provides empirical support that the second shareholder will influence the extent to which firms cater to their investors' sentiments, because when this second shareholder doesn't exist and the ownership by the first is high, the catering effect turns negative. Finally, the results obtained reveal important differences in the ability of dividend catering to explain a firm's propensity to pay dividends when the second shareholder has the possibility to contest the ability to expropriate by largest shareholder. The results are coherent with the previous ones showing that the catering effect of dividends is positively affected by the ability of the second shareholder in challenging the first shareholder through contestability; however, this effect turns negative with the presence of blockholders, the first and second shareholders, who, by colluding, can increase the possibility of private benefits extraction.

\section{Acknowledgements}

I am very grateful to Professors Dr. Julio Pindado Garcia, and Chabela de la Torre at Salamanca University, for their suggestions and comments.

\section{References}

Adams, R. B., \& Ferreira, D. (2008). One Share, One Vote: The Empirical Evidence. Review of Finance, 12, 51-91. http://dx.doi.org/10.1093/rof/rfn003

Adams, R. B., Almeida, H., \& Ferreira, D. (2005). Poweful CEOs and their impact on corporate performance. Review of Financial Studies, 18, 1403-1432. http://dx.doi.org/10.1093/rfs/hhi030

Agrawal, A., \& Jayoraman, N. (1994). The Dividend Policies of All-Equity Firms: A Direct Test of the Free Cash Flow Theory. Managerial Decision Economic, 15, 139-148. http://dx.doi.org/10.1002/mde.4090150206

Alford, A., Jones, J., Leftwich, R., \& Zmijewski, M. (1993). The relative informativeness of accounting disclosure in different countries. Journal of Accounting Research, 31, 183-223. http://dx.doi.org/10.2307/2491170

Ali, A., \& Hwang, L.S. (2000). Country-specific factors related to financial reporting and the value relevance of accounting data. Journal of Accounting Research, 38, 1-21. http://dx.doi.org/10.2307/2672920 
Allen, F., \& Michaely, R. (2003). Payout policy. In Constantinides, George, Milton Harris, and Réne Stulz (Eds.), Handbook of Economics (pp. 337-430). North Holland, Amsterdam.

Almeida, H., \& Wolfenzon, D. (2006). A theory of pyramidal ownership and family business groups. Journal of Finance, 61, 2637-2680. http://dx.doi.org/10.1111/j.1540-6261.2006.01001.x

Amihud, Y., \& Murgia, M. (1997). Dividends, Taxes, and Signaling: Evidence from Germany. Journal of Finance, 52, 397-408. http://dx.doi.org/10.1111/j.1540-6261.1997.tb03822.x

Ang, A., Bekaert, G., \& Wei, M. (2006). Do macro variables, asset markets or surveys forecast inflation better? Finance and Economics Discussion Series 2006/15.

Arellano, M., \& Bond, S. (1991). Some tests of specification for panel data: Monte Carlo evidence and an application to employment equations. Review of Economic Studies, 58, 277-297. http://dx.doi.org/10.2307/2297968

Auerbach, A., \& Hassett, K. (2003). On the marginal source of investment funds. Journal of Public Economics, 87, 205-232. http://dx.doi.org/10.1016/S0047-2727(01)00172-4

Baker, K., Powell, G., \& Veit, T. (2002). Revisiting managerial perspectives on dividend policy. Journal of Economics and Finance, 26, 267-283. http://dx.doi.org/10.1007/BF02759711

Baker, M., \& Wurgler, J. (2004a). A catering theory of dividends. Journal of Finance, 59, 1125-1165. http://dx.doi.org/10.1111/j.1540-6261.2004.00658.x

Baker, M., \& Wurgler, J. (2004b). Appearing and disappearing dividends: The link to catering incentives. Journal of Financial Economics, 73, 271-288. http://dx.doi.org/10.1016/j.jineco.2003.08.001

Baker, M., \& Wurgler, J. (2006). Investor Sentiment and the Cross-section of Stock Returns. Journal of Finance, 61, 1645-1680. http://dx.doi.org/10.1111/j.1540-6261.2006.00885.x

Baker, M., \& Wurgler, J. (2007). Investor sentiment in the stock market. Journal of Economic Perspectives, 21, 129-151. http://dx.doi.org/10.1257/jep.21.2.129

Baker, M., Stein, J., \& Wurgler, J. (2003). When Does the Market Matter? Stock Prices and the Investment of Equity-Dependent Firms. Quarterly Journal of Economics, 118, 969-1006. http://dx.doi.org/10.1162/00335530360698478

Bali, R. (2003). Variation in Ex Day Dividend Pricing: Myth or Reality? Journal of Economics \& Finance, 27, 190-210. http://dx.doi.org/10.1007/BF02827218

Bandopadhyaya, A., \& Jones, L. (2006). Measuring Investor Sentiment in Equity Markets. Journal of Asset Management, 208-215. http://dx.doi.org/10.1057/palgrave.jam.2240214

Barber, B. M., \& Odean, T. (2000). Trading is hazardous to your wealth: The common stock investment performance of individual investors. Journal of Finance, 55, 773-806. http://dx.doi.org/10.1111/0022-1082.00226

Barberis, N., Shleifer, A., \& Vishny, R. (1998). A model of investor sentiment. Journal of Financial Economics, 49, 307-343. http://dx.doi.org/10.1016/S0304-405X(98)00027-0

Barclay, M., Holderness, C. G., \& Pontiff, J. (1993). Private benefits from block ownership and discounts on closed-end funds. Journal of Financial Economics, 33, 263-291. http://dx.doi.org/10.1016/0304-405X(93)90008-Y

Bebchuk, L. A. (1999). A rent-protection theory of corporate ownership and control. Working Paper, $\mathrm{N}^{\circ} 7203$, National Bureau of Economic Research, (Cambridge, MA).

Bebchuk, L. A., Kraakman, R., \& Triantis, G. (2000). Stock pyramids, cross-ownership, and dual class equity: the creation and agency costs of separating control from cash flow rights. In Morck, R. (Ed.), Concentrated Corporate Ownership (pp.295-315).

Becht, M., Bolton, P., \& Röell, A. (2003). Corporate Governance and Control. In G. Constantinides, M. Harris and R. Stulz (Eds.), The Handbook of the Economics of Finance (1, pp.1-109). North-Holland.

Bell, L., \& Jenkinson, T. (2002). New Evidence of the Impact of Dividend Taxation and on the Identity of the Marginal Investor. Journal of Finance, 57, 1321-1346. http://dx.doi.org/10.1111/1540-6261.00462

Bennedsen, M., \& Wolfenzon, D. (2000). The balance of power in closely held corporations. Journal of Financial Economics, 58, 113-139. http://dx.doi.org/10.1016/S0304-405X(00)00068-4 
Benson, B., \& Davidson, W.N. (2009). Reexamining the managerial ownership effect on firm value. Journal of Corporate Finance, 15, 573-586. http://dx.doi.org/10.1016/j.jcorpfin.2009.08.002

Bertrand, M., \& Schoar, A. (2003). Managing with Style: The Effect of Managers on Firm Policies. Quarterly Journal of Economics, 118, 1169-1208. http://dx.doi.org/10.1162/003355303322552775

Bettis, C., Bizjak, J., \& Lemmon, M. (2001). Managerial Ownership, Incentive Contracting, and the Use of Zero-Cost Collars and Equity Swaps by Corporate Insiders. Journal of Financial and Quantitative Analysis, 36, 345-370. http://dx.doi.org/10.2307/2676287

Brennan, M., \& Tamarowski, C. (2000). Investor relations, liquidity and stock prices. Journal of Applied Corporate Finance, 12, 26-37. http://dx.doi.org/10.1111/j.1745-6622.2000.tb00017.x

Brown, G. W., \&. Cliff, M. T. (2004). Investor sentiment and the near-term stock market. Journal of Empirical Finance, 11, 1-27. http://dx.doi.org/10.1016/j.jempfin.2002.12.001

Brown, G. W., \&. Cliff, M. T. (2005). Investor Sentiment and Asset Valuation. Journal of Business, 78, 405-440. http://dx.doi.org/10.1086/427633

Brown, J.R., Liang, N., \& Weisbenner, S. (2007). Executive Financial Incentives and Payout Policy: Firm Response to the 2003 Dividend Tax Cut. Journal of Finance, 62, 1935-1965. http://dx.doi.org/10.1111/j.1540-6261.2007.01261.x

Chay, J-B., \& Suh, J. (2006). Cross-sectional determinants of dividend payments: International evidence, Working Paper, (Sungyungkwan University).

Chiu, H. (2006). Investor preferences, mutual fund flows, and the timing of IPOs, Working Paper.

Claessens, S., Djankov, S., \& Lang, L.H.P. (2000). The separation of ownership and control in East Asian corporations. Journal of Financial Economics, 58, 81-112. http://dx.doi.org/10.1016/S0304-405X(00)00067-2

Claessens, S., Djankov, S., Fan, J., \& Lang, L.H.P. (1999). Expropriation of minority shareholders: Evidence from East Asia. Policy ResearchWorking Paper, No 2088 (The World Bank, Washington D.C.).

Claessens, S., Djankov, S., Fan, J., \& Lang, L.H.P. (2002). Disentangling the incentive and entrenchment effects of large shareholdings. Journal of Finance, 57, 2741-2771. http://dx.doi.org/10.1111/1540-6261.00511

Coles, J., Suay, J., \& Woodbury, D. (2000). Fund advisor compensation in closed-end funds. Journal of Finance, 55, 1385-1414. http://dx.doi.org/10.1111/0022-1082.00251

Conrad, J., Cornell, B., \& Landsman, W. (2002). When is bad news really bad news? Journal of Finance, 57, 2507-2532. http://dx.doi.org/10.1111/1540-6261.00504

Correia, S., Goergen, M., \& Renneboog, L. (2004). Dividend Policy and Corporate Governance, ECGI. Oxford University Press. http://dx.doi.org/10.1093/0199259305.001.0001

Correia, S., Goergen, M., \& Renneboog, L. (2005). When Do German Firms Change Their Dividends? Journal of Corporate Finance, 11, 375-399. http://dx.doi.org/10.1016/j.jcorpfin.2003.09.001

Crespi, R. (1997). A Survey on Spanish Corporate Governance Rules, Statistics and Institutions. The Separation of Ownership and Control: A Survey of 7 European Countries, Preliminary Report to the European Commission.

Dahya, J., Dimitrov, O., \& McConnell, J. (2008). Dominant shareholders, corporate boards, and corporate value: A cross-country analysis. Journal of Financial Economics, 87, 73-100. http://dx.doi.org/10.1016/j.jfineco.2006.10.005

De Long, B., Shleifer, A., Summers, L. H., \& Waldmann, R. J. (1990). Noise trader risk in financial markets. Journal of Political Economy, 98, 703-738. http://dx.doi.org/10.1086/261703

Demsetz, H. (1983). The Structure of Ownership and the Theory of the Firm. Journal of Law and Economics, 26, 301-325. http://dx.doi.org/10.1086/467041

Demsetz, H., \& Villalonga, B. (2001). Ownership Structure and Corporate Performance. Journal of Corporate Finance, 7, 209-233. http://dx.doi.org/10.1016/S0929-1199(01)00020-7

Denis, D., \& Osobov, I. (2008). Why Do Firms Pay Dividends? International Evidence on the Determinants of Dividend Policy. Journal of Financial Economics, 89, 62-82. http://dx.doi.org/10.1016/j.jfineco.2007.06.006

Dittmar, A., \& Mahrt-Smith, J. (2007). Corporate Governance and the Value of Cash Holdings. Journal of Financial Economics, 83, 599-634. http://dx.doi.org/10.1016/j.jfineco.2005.12.006 
Dittmar, A., Mahrt-Smith, J., \& Servaes, H. (2003). International corporate governance and corporate cash holdings. Journal of Financial and Quantitative Analysis, 38, 111-133. http://dx.doi.org/10.2307/4126766

Dyck, A., \& Zingales, L. (2004). Private benefits of control: An international comparison. Journal of Finance, 59, 537-600. http://dx.doi.org/10.1111/j.1540-6261.2004.00642.x

Easterbrook, F. (1984). Two Agency-Cost Explanations of Dividends. American Economic Review, 74, 650-60.

Edmans, A., García, D., \& Norli, Ø. (2007). Sports sentiment and stock returns. Journal of Finance, 62, $1967-1998$. http://dx.doi.org/10.1111/j.1540-6261.2007.01262.x

Faccio, M., \& Lang, L. H. P. (2002). The Ultimate Ownership of Western European Corporations. Journal of Financial Economics, 65, 365-395. http://dx.doi.org/10.1016/S0304-405X(02)00146-0

Faccio, M., Lang, L. H. P., \& Leslie Young. (2001). Dividends and Expropriation. American Economic Review, 91, 54-78. http://dx.doi.org/10.1257/aer.91.1.54

Fairchild, R., \& Zhang, G. (2005). Investor Irrationality and Optimal Open-market Share Repurchasing. Journal of Behavioral Finance, 2, 17-31.

Fama, E. F., \& French, K. R. (2001). Disappearing dividends: Changing firm characteristics or lower propensity to pay? Journal of Financial Economics, 60, 3-44. http://dx.doi.org/10.1016/S0304-405X(01)00038-1

Fama, E. F., \& Jensen, M. C. (1983). Separation of ownership and control. Journal of Law and Economics, 26, 301-325. http://dx.doi.org/10.1086/467037

Farinha, J. (2003). Dividend Policy, Corporate Governance and The Managerial Entrenchment Hypothesis: An Empirical Analysis. Journal of Business, Finance \& Accounting, 30, 1173-1209. http://dx.doi.org/10.1111/j.0306-686X.2003.05624.x

Fenn, G. W., \& Liang, N. (2001). Corporate Payout Policy and Managerial Stock Incentives. Journal of Financial Economics, 60, 45-72. http://dx.doi.org/10.1016/S0304-405X(01)00039-3

Ferris, S. P., Sen, N., \& Yui, H. (2006). God Save the Queen and her dividends: Corporate payout in the United Kingdom. Journal of Business, 79, 1149- 1173. http://dx.doi.org/10.1086/500672

Ferris, S. P., Narayanan, J., \& Sanjiv, S. (2008). International Differences in Dividend Policy: Catering, Legal, and Cultural Effects, Working Paper (under review).

Filatotchev, I., Kepelyushnikov, R., Dyomina, N., \& Aukusionek, S. (2001). The effects of ownership concentration on investment and performance in privatised firms in Russia. Managerial and Decision Economics, 22, 299-313. http://dx.doi.org/10.1002/mde.1008

Frazzini, A., \& Lamont, O. (2005). Dumb Money: Mutual Fund Flows and the Cross-Section of Stock Returns, NBER Working Paper, No 11526.

Gemmill, G. (2005). Catering for dividends by stripping mutual-fund portfolios, SSRN Working paper, No 807904.

Ginglinger, E., \& L'Her, J-F. (2006). Ownership structure and open market stock repurchases in France. European Journal of Finance, 12, 77-94. http://dx.doi.org/10.1080/13518470500039543

Gompers, P. A., Ishii, J., \& Metrick, A. (2006). Extreme Governance: An Analysisof Dual-Class Firms in the United States, Working paper (Harvard, Stanford, and Wharton).

Graham, J., \& Kumar, A. (2006). Do Dividend Clienteles Exist? Evidence on Dividend Preferences of Retail Investors. Journal of Finance, 61, 1305-1336. http://dx.doi.org/10.1111/j.1540-6261.2006.00873.x

Grinstein, Y., Michaely, R. (2005). Institutional Holdings and Payout Policy. Journal of Finance, 60, $1389-1426$. http://dx.doi.org/10.1111/j.1540-6261.2005.00765.x

Grossman, S. J., \& Hart, O. (1980). Takeover bids, the free - rider problem, and the theory of the corporation. Bell Journal of Economics, 11, 42-64. http://dx.doi.org/10.2307/3003400

Grossman, S. J., \& Hart, O. (1988). One share-one vote and the market for corporate control. Journal of Financial Economics, 20, 175-202. http://dx.doi.org/10.1016/0304-405X(88)90044-X

Gugler, K. (2003). Corporate Governance, Dividend Payout Policy, and the Interrelation Between Dividends, R\&D, and Capital Investment. Journal of Banking and Finance, 27, 1297-1321. http://dx.doi.org/10.1016/S0378-4266(02)00258-3 
Gugler, Klaus, \& Burcin Yurtoglu. (2003). Corporate governance and dividend pay-out policy in Germany. European Economic Review, 47, 731-758. http://dx.doi.org/10.1016/S0014-2921(02)00291-X

Gugler, K., Mueller, D., \& Yurtoglu, B. (2008). Insider ownership, ownership concentration and investment performance: An international comparison. Journal of Corporate Finance, 14, 688-705. http://dx.doi.org/10.1016/j.jcorpfin.2008.09.007

Hansen, R. S., Kumar, R., \& Shome, D. K. (1994). Dividend Policy and Corporate Monitoring: Evidence from the Regulated Electric Utility Industry. Financial Management, 16-22. http://dx.doi.org/10.2307/3666052

Hoberg, G., \& Prabhala, N. (2009). Disappearing dividends: the importance of idiosyncratic risk and the irrelevance of catering. Review of Financial Studies, 22, 79-116. http://dx.doi.org/10.1093/rfs/hhn073

Holder, M., Langrehr, F., \& Hexter, L. (1998). Dividend Policy Determinants. An Investigation of the Influences of Stakeholder Theory. Financial Management, 27, 73-82. http://dx.doi.org/10.2307/3666276

Hong, H., \& Huang, M. (2005). Talking up liquidity: insider trading and investor relations. Journal of Financial Intermediation, 14, 1-31. http://dx.doi.org/10.1016/j.jfi.2003.08.004

Hu, A., \& Kumar, P. (2004). Managerial Entrenchment and Payout Policy. Journal of Financial \& Quantitative Analysis, 39, 759-790. http://dx.doi.org/10.1017/S0022109000003203

Hu, Y., Wang, D., \& Zhang, S. (2007). Founding Family Ownership, Management and Payout Policy, SSRN Working paper, No 1024300.

Jensen, G. R., Solberg, D., \&. Zorn, T. S. (1992). Simultaneous Determination of Insider Ownership, Debt, and Dividend Policies. The Journal of Financial and Quantitative Analysis, 27, 247-263. http://dx.doi.org/10.2307/2331370

Jensen, M. (1986). Agency Costs of Free Cash Flow, Corporate Finance, and Takeovers. American Economic Review, $76,323-329$.

Jensen, M., \& Meckling, W. (1976). Theory of the Firm: Managerial Behavior, Agency Costs, and Ownership Structure. Journal of Financial Economics, 3, 305-360. http://dx.doi.org/10.1016/0304-405X(76)90026-X

Jensen, M., \& Murphy, K. (1990). Performance Pay and Top-Management Incentives. Journal of Political Economy, 98, 225-264. http://dx.doi.org/10.1086/261677

Kahle, K. (2002). When a Buyback isn't a Buyback: Open-market Repurchases and Employee Options. Journal of Financial Economics, 63, 235-261. http://dx.doi.org/10.1016/S0304-405X(01)00095-2

Kamstra, M., Kramer, L., \& Levi, M. (2003). Winter Blues: A SAD Stock Market Cycle. American Economic Review, 93, 324-343. http://dx.doi.org/10.1257/000282803321455322

Kaniel, R, Saar, G., \& Titman, S. (2006). Individual investor sentiment and stock returns. Johnson School Research Paper Series 13.

Khan, T. S. (2006). Company Dividends and Ownership Structure: Evidence from UK Panel Data. Economic Journal, 116, 172-189. http://dx.doi.org/10.1111/j.1468-0297.2006.01082.x

Khorana, A., Wahal, S., \&c Zenner, M. (2002). Agency conflicts in closed-end funds: The case of rights offerings. Journal of Financial and Quantitative Analysis, 37, 177-200. http://dx.doi.org/10.2307/3595002

Klapper, L., \& Love, I. (2004). Corporate governance, investor protection, and performance in emerging markets. Journal of Corporate Finance, 10, 703-728. http://dx.doi.org/10.1016/S0929-1199(03)00046-4

Koch, A. S., \& Sun, A. X. (2004). Dividend changes and the persistence of past earnings changes. Journal of Finance, 59, 2093-2116. http://dx.doi.org/10.1111/j.1540-6261.2004.00693.x

Kumar, A., \& Lee, C. M. (2006). Retail Investor Sentiment and Return Comovements. Journal of Finance, 61, 2451-2486. http://dx.doi.org/10.1111/j.1540-6261.2006.01063.x

Laeven, L., \& Levine, R. (2004). Beyond the Biggest: Do Other Large Shareholders Influence Corporate Valuations, Working Paper, (University of Minnesota).

Lai, R. (2004). A catering theory of analyst bias, SSRN Working Paper, No.548582.

Lambert, R., Lanen, W., \& Larcker, D. (1989). Executive stock option plans and dividend policy. Journal of Financial and Quantitative Analysis, 24, 409-425. http://dx.doi.org/10.2307/2330976 
Lang, L., \& Litzenberger, R. (1989). Dividend announcements: cash flow signalling vs. free cash flow hypothesis? Journal of Financial Economics, 24, 181- 192. http://dx.doi.org/10.1016/0304-405X(89)90077-9

La Porta, R., Lopez-de-Silanes, F., \& Shleifer, A. (1999). Corporate Ownership around the World. Journal of Finance, 54, 471-517. http://dx.doi.org/10.1111/0022-1082.00115

La Porta, Rafael, Florencio Lopez-de-Silanes, Andrei Shleifer, \& Robert Vishny. (1998). Law and Finance. Journal of Political Economy, 106, 1113-1155. http://dx.doi.org/10.1086/250042

La Porta, R., Lopez-de-Silanes, F., Shleifer, A., \& Vishny, R. (2000a). Agency problems and dividend policies around the world. Journal of Finance, 55, 1-33. http://dx.doi.org/10.1111/0022-1082.00199

La Porta, R., Lopez-de-Silanes, F., Shleifer, A., \& Vishny, R. (2000b). Investor Protection and Corporate Governance. Journal of Financial Economics, 58, 3-28. http://dx.doi.org/10.1016/S0304-405X(00)00065-9

La Porta, R., Lopez-de-Silanes, F., Shleifer, A., \& Vishny, R. (2002). Investor Protection and Corporate Valuation. Journal of Finance, 57, 1147-1170. http://dx.doi.org/10.1111/1540-6261.00457

Lasfer, A. (1996). Taxes and Dividends: The UK Evidence. Journal of Banking and Finance, 20, 455-472. http://dx.doi.org/10.1016/0378-4266(95)00012-7

Lee, C., Shleifer, A., \& Thaler, R. (1991). Investor sentiment and the closed-end fund puzzle. Journal of Finance, 46, 75-110. http://dx.doi.org/10.1111/j.1540-6261.1991.tb03746.x

Lee, W., Jiang, C., \& Indro, D. (2002). Stock market volatility, excess returns, and the role of investor sentiment. Journal of Banking and Finance, 26, 2277-2299. http://dx.doi.org/10.1016/S0378-4266(01)00202-3

Lemmon, M., \& Lins, K. (2003). Ownership structure, corporate governance, and firm value: evidence from the East Asian financial crisis. Journal of Finance, 58, 1445-1468. http://dx.doi.org/10.1111/1540-6261.00573

Lemmon, M., \& Portniaguina, E. (2006). Consumer Confidence and Asset Prices: Some Empirical Evidence. Review of Financial Studies, 19, 1499-1529. http://dx.doi.org/10.1093/rfs/hhj038

Li, W., \& Lie, E. (2006). Dividend changes and catering incentives. Journal of Financial Economics, 80, 293-308. http://dx.doi.org/10.1016/j.jfineco.2005.03.005

Lins, K. V. (2003). Equity ownership and firm value in emerging markets. Journal of Financial and Quantitative Analysis, 38, 159-184. http://dx.doi.org/10.2307/4126768

Lloyd, W., Jahera, J., \& Page, D. (1985). Agency Costs and Dividend- Payout Ratios. Quarterly Journal of Business and Economics, 24, 19-29.

Lo, W-C., \& Lin, K-J. (2005). A Review of the Effects of Investor Sentiment on Financial Markets: Implication for Investors. International Journal of Management, 22, 708-715.

López-de-Foronda, O., López-Iturriaga, F., \& Bertin, M. (2008). The contest to the control in European Family Firms: How Other Shareholders Affect Firm Value. Corporate Governance, 16, 146-159. http://dx.doi.org/10.1111/j.1467-8683.2008.00677.x

Maug, E. (1998). Large Shareholders as Monitors: Is There a Trade-off between Liquidity and Control? Journal of Finance, 53, 65-98. http://dx.doi.org/10.1111/0022-1082.35053

Maury, B., \& Pajuste, A. (2002). Controlling Shareholders, Agency Problems and Dividend Policy in Finland. Finnish Journal of Business Economics, 51, 15-45.

Maury, B., \& Pajuste, A. (2005). Multiple large shareholders and firm value. Journal of Banking \& Finance, 29, 1813-1834. http://dx.doi.org/10.1016/j.jbankfin.2004.07.002

McDonald, R. (2001). Cross-border investing with tax arbitrage: The case of German dividend tax credits. Review of Financial Studies, 14, 617-657. http://dx.doi.org/10.1093/rfs/14.3.617

Michaely, R., \& Roberts, M. (2007). Corporate Dividend Policies: Lessons from Private Firms. SSRN Working Paper, No. 927802.

Miguel, A., Pindado, J., \& de la Torre, C. (2005). How do entrenchment and expropriation phenomena affect control mechanisms? Corporate Governance: An Internacional Review, 13, 505-516. http://dx.doi.org/10.1111/j.1467-8683.2005.00445.x

Miller, M., \& Modigliani, F. (1961). Dividend Policy, Growth and the Valuation of Shares. Journal of Business, 34, 411-433. http://dx.doi.org/10.1086/294442 
Miller, M., \& Rock, K. (1985). Dividend policy under asymmetric information. Journal of Finance, 40, 1031-1051. http://dx.doi.org/10.1111/j.1540-6261.1985.tb02362.x

Modigliani, F., \& Perotti, E. (1997). Protection of minority interest and the development of security markets. $\begin{array}{lllll}\text { Managerial and Decision } & \text { Economics, } & \text { 519-528. }\end{array}$ http://dx.doi.org/10.1002/(SICI)1099-1468(199711/12)18:7/8<519::AID-MDE857>3.0.CO;2-M

Moh'd, M., Perry, L., \& Rimbey, J. (1995). An Investigation of the Dynamic Relationship between Agency Theory and Dividend Policy. Financial Review, 30, 367-385. http://dx.doi.org/10.1111/j.1540-6288.1995.tb00837.x

Morck, R., \& Yeung, B. (2005). Dividend taxation and corporate governance. Journal of Economic Perspectives, 19, 163-180. http://dx.doi.org/10.1257/089533005774357752

Morck, R., Shleifer, A., \& Vishny, R. W. (1988). Management Ownership and Market Valuation: An Empirical Analysis. Journal of Financial Economics, 20, 293-315. http://dx.doi.org/10.1016/0304-405X(88)90048-7

Neal, R., \& Wheatley, S. (1998). Do measures of investor sentiment predict stock returns. Journal of Financial and Quantitative Analysis, 34, 523-547. http://dx.doi.org/10.2307/2331130

Nenova, T. (2003). The value of corporate voting rights and control: a crosscountry analysis. Journal of Financial Economics, 68, 325-351. http://dx.doi.org/10.1016/S0304-405X(03)00069-2

Neves, E., Pindado, J., \& de la Torre, C. (2006). Dividends: New evidence on the catering Theory. Working Paper $\mathrm{n}^{\circ}$ 14/2006, Nuevas tendencies en direction de empresas, Universidad de Salamanca.

Odean, T. (1998). Are Investors Reluctant to Realize Their Losses? Journal of Finance, 53, 1775-1798. http://dx.doi.org/10.1111/0022-1082.00072

Oswald, D., \& Young, S. (2004). What Role Taxes and Regulation? A Second Look at Open Market Share Buyback Activity in the UK. Journal of Business Finance and Accounting, 31, 257-292. http://dx.doi.org/10.1111/j.0306-686X.2004.0007.x

Perez-Gonzalez, F. (2003). Large Shareholders and Dividends: Evidence from U.S. Tax Reform. Working paper (Columbia University).

Pinkowitz, L., Stulz, R., \& Williamson, R. (2006). Does the contribution of corporate cash holdings and dividends to firm value depend on governance? A cross-country analysis. Journal of Finance, 61, 2725- 2751. http://dx.doi.org/10.1111/j.1540-6261.2006.01003.x

Puri, M., \& Robinson, D.T. (2007). Optimism and economic choice. Journal of Financial Economics, 86, 71-99. http://dx.doi.org/10.1016/j.jfineco.2006.09.003

Qiu, L., \& Welch, I. (2006). Investor Sentiment Measures. SSRN Working Paper, No 589641.

Rau, R., \& Vermaelen, T. (2002). Regulation, Taxes, and Share Repurchases in the United Kingdom. Journal of Business, 75, 245-282. http://dx.doi.org/10.1086/338703

Renneboog, L., \& Trojanowski, G. (2006). Control Structures and payout policy. Managerial Finance, 33, 43-64. http://dx.doi.org/10.1108/03074350710715809

Renneboog, L., \& Szilagyi, P. (2007). How Relevant is Dividend Policy under Low Shareholder protection? ECGI, Finance Working Paper, No 128.

Richardson, S., Teoh, S. H., \& Wysocki, P. (2001).The walkdown to beatable analyst forecasts: The roles of equity issuance and insider trading incentives, Working Paper, (Univ. of Michigan Business School).

Rozeff, M. (1982). Growth, beta and agency costs as determinants of dividend payout ratios. Journal of Financial Research, 5, 249-259.

Schmitz, P., Glaser, M., \& Weber, M. (2005). Individual Investor sentiment and Stock Returns - What Do we Learn from Individual Warrant Traders? Working Paper, (University of Mannheim).

Schooley, D., \& Barney, D. (1994). Using Dividend Policy and Managerial Ownership to Reduce Agency Costs. Journal of Financial Research, 17, 363-73.

Shleifer, A., \& Vishny, R. (1986). Large shareholders and corporate control. Journal of Political Economy, 94, 461-488. http://dx.doi.org/10.1086/261385

Shleifer, A., \& Vishny, R. (1997). A survey of corporate governance. Journal of Finance, 52, 737-783. http://dx.doi.org/10.1111/j.1540-6261.1997.tb04820.x 
Shleifer, A., \& Wolfenzon, D. (2002). Investor protection and equity markets. Journal of Financial Economics, 66, 3-27. http://dx.doi.org/10.1016/S0304-405X(02)00149-6

Short, H., Zhang, H., \& Keasey, K. (1999). Managerial Ownership and The Performance Of Firms: Evidence From The U.K.. Journal of Corporate Finance, 5, 79-101. http://dx.doi.org/10.1016/S0929-1199(98)00016-9

Short, H., Zhang, H., \& Keasey, K. (2002). The link between dividend policy and institutional ownership. Journal of Corporate Finance, 8, 105-22. http://dx.doi.org/10.1016/S0929-1199(01)00030-X

Solt, M. E., \& Statman, M. (1989). Good Companies, Bad Stocks. Journal of Portfolio Management, 39-44. http://dx.doi.org/10.3905/jpm.1989.409219

Stulz, R. (1988). Managerial Control of Voting Rights: Financing Policies and the Market for Corporate Control. Journal of Financial Economics, 20, 25-54. http://dx.doi.org/10.1016/0304-405X(88)90039-6

Stulz, R. (1990). Managerial discretion and optimal financing policies. Journal of Financial Economics, 26, 3-28. http://dx.doi.org/10.1016/0304-405X(90)90011-N

Thomsen, S. (2005). Conflicts of Interest or Aligned Incentives? Blockholder Ownership, Dividends and Firm Value in the US and the EU European Business Organization. Law Review, 6, 201-225. http://dx.doi.org/10.1017/S1566752905002016

Thomsen, S., \& Pedersen, T. (2000). Ownership structure and economic performance in the largest European companies. Strategic Management http://dx.doi.org/10.1002/(SICI)1097-0266(200006)21:6<689::AID-SMJ115>3.0.CO;2-Y

Tse, C-B. (2005). Use dividends to signal or not: An examination of the UK dividend payout patterns. Managerial Finance, 31, 12-33. http://dx.doi.org/10.1108/03074350510769596

Volpin, P. (2002). Governance with Poor Investor Protection: Evidence from Top Executive Turnover in Italy. Journal of Financial Economics, 64, 61-90. http://dx.doi.org/10.1016/S0304-405X(02)00071-5

Von Eije, H., \& Megginson, W. (2008). Dividends and share repurchases in the European Union. Journal of Financial Economics, 89, 347-374. http://dx.doi.org/10.1016/j.jfineco.2007.11.002

Wang, C. (2003). Investor sentiment, market timing, and futures returns. Applied Financial Economics, 13, 891-898. http://dx.doi.org/10.1080/0960310032000129653

Wang, Y., Keswani, A., \& Taylor, S. J. (2006). The relationships between sentiment, returns and volatility. International Journal of Forecasting, 22, 109-123. http://dx.doi.org/10.1016/j.ijforecast.2005.04.019

Weisbenner, S. (2000). Corporate Share Repurchases in the 1990s: What Role do Stock Options Play? Board of Governors of the Federal Reserve System, Finance and Economics Discussion Paper 2000/29.

Wolfenzon, D. (1999). A theory of pyramidal ownership. Unpublished Working Paper, (Harvard University), Cambridge, MA.

Zhang, F. (2006). Information uncertainty and stock returns. Journal of Finance, 61, 105-137. http://dx.doi.org/10.1111/j.1540-6261.2006.00831.x

\section{Notes}

Note 1. Prior studies have provided significant insights into how agency conflicts affect a firm's payout policy. See, for instance, Fenn and Liang (2001), and Michaely and Roberts (2007) for US firms; and La Porta et al. (2000a), and Faccio, Lang and Young (2001) for cross- country analyses.

Note 2. Recently researchers have investigated the interaction between dividend policies and various ownership characteristics of public firms, and find mixed results. See, for example, Fenn and Liang (2001), Perez-Gonzalez (2003), Grinstein and Michaely (2005), Graham and Kumar (2006), and Brown, Liang and Weisbenner (2007), among others.

Note 3. Baker, Powell and Veit (2002a) focus on the managerial perspectives dividend policy to show that managers of NASDAQ firms strongly believe that dividend policy matters. In other words, dividend policy influences stock prices. This result is inconsistent with the irrelevance proposition of Miller and Modigliani (1961), and is explained by the imperfections of the market.

Note 4. Studies for the UK show that there is a negative relationship between insider ownership and dividends. See, for instance, Short, Zhang and Keasey (2002); Farinha (2003), and Renneboog and Trojanowski (2006). 
Note 5. See, for instance, Shleifer and Vishny (1997), La Porta, Lopez-de-Silanes and Shleifer (1999), Claessens, Djankov and Lang (2000), Faccio and Lang (2002), Becht, Bolton and Röell (2003), or Farinha (2003), who suggest that the relevant agency problem is not the one between corporate managers and shareholders but rather between controlling shareholders and minority shareholders.

Note 6. This finding is supported by the lower cash holdings of better-governed firms reported in Dittmar, Mahrt-Smith and Servaes (2003), and more recently, in Dittmar and Mahrt-Smith (2007).

Note 7. Note that a considerable amount of research has examined the influence of ownership and control structures on firms' financing decisions and performance in United States and United Kingdom.

Note 8. Some authors, for instance, La Porta et. al, (2000a), Thomsen (2005), Chay and Suh (2006), or Pinkowitz, Stulz and Williamson (2006), Denis and Osobov (2008), and von Eije and Megginson (2008) study this subject for more than a country; however, for a reduced number of countries of Eurozone.

Note 9. Private benefits of control by dominant owners are the focus of Grossman and Hart (1988), Modigliani and Perotti (1997), Bebchuck (1999), Bebchuck, Kraakman and Triantis (2000), Shleifer and Wolfenzon (2002), Almeida and Wolfenzon (2006), among others.

Note 10. An example of one concrete industry is demonstrated for Hansen, Kumar and Shome (1994), who show that payout ratios of electric utilities respond in much the same fashion as unregulated firms when the concentration of ownership changes. Their findings suggest that as the concentration of ownership increases, the level of monitoring increases and the need for a higher dividend payout decreases.

Note 11. For an interesting study on relationship between Insider ownership, ownership concentration and investment performance see Gugler, Mueller and Yurtoglu (2008).

Note 12. See, for instance, Lambert, Lanen and Larcker (1989); Jolls (1998); Weisbenner (2000); Bettis, Bizjak and Lemmon (2001), Fenn and Liang (2001), Kahle (2002); Hu and Kumar (2004) or Brown, Liang and_Weisbenner (2007), among others.

Note 13. Stulz (1988, 1990); Shleifer and Vishny (1997); Claessens et al. (2002), and La Porta et al. (2002), show that ownership structures can affect corporate policies and firm value in the context of managerial entrenchment.

Note 14. See, for instance, Jensen, Solberg and Zorn (1992); Agrawal and Jayoraman (1994). They find that if the insider owners hold the major shares of the company then management naturally prefers not to declare more dividends, then, the level of managerial stock ownership has a negative impact on firms' dividend levels.

Note 15. For example, Grossman and Hart (1988) document that large insiders may have a preference for retained earnings over dividends for rent extraction.

Note 16. Alford, Jones, Leftwich and Zmijewski (1993) and Ali and Hwang (2000) show that managerial entrenchment and the subsequent abuses of minority shareholders are more relevant in Continental European countries where the legal protection of minority shareholders is weak and firms often adopt anti-shareholder devices that violate the one-share-one-vote rule (La Porta et al., 1998). Others studies report that weak shareholder protection is associated with more severe expected agency costs of managerial entrenchment (see, for instance, La Porta et al., 2002; Claessens et al., 2002; Lins, 2003; Klapper and Love, 2004).

Note 17. Morck, Shleifer, and Vishny (1988), and Stulz (1988) find a non-monotonic empirical relationship between management ownership and firm value. For studies on the relationship between ownership structures and firm value, see for example, Demsetz and Villalonga (2001), Gompers, Ishii and Metrick (2006), and Adams and Ferreira (2008).

Note 18. See, for instance, Lemmon and Lins (2003) for an important research on ownership structure and firm value in East Asia. Likewise, Laeven and Levine (2004) shows for 13 Western European countries that over forty percent of the public firms with one large shareholder have two or more owners holding more than 10 percent of the voting rights each. Moreover, they show that firm value increases with the equity stake of a second large shareholder only if the gap in voting rights between the first and the second largest shareholder is small, as one would expect to occur in governance structures under shared control. These findings confirm the results by Volpin (2002), who document that 15 percent of the firms listed in the Milan Stock Exchange were controlled by large shareholders that entered into explicit agreements to vote as a block. More recently, and in the same vein of research, López-de-Foronda, López-Iturriaga and Bertin (2008) show, from 11 European countries, that existence of a controlling coalition in family-owned firms and the contestability of control of the largest shareholder affect the value of the family-owned firms. 
Note 19. For instance, Claessens et al. (1999) find that concentrated ownership contributes to higher profitability and market valuation. Thomsen and Pedersen (2000) find a high correlation between ownership share of the largest owner and the closely held shares measure.

Note 20. Wolfenzon (1999), and Faccio, Lang and Young (2001) argue that the possibility for expropriation is larger when the corporation is affiliated to a group of corporations, everything controlled by the same shareholder.

Note 21. Renneboog and Trojanowski (2006) find that in the UK payout levels are lowest in firms controlled by individual investors.

Note 22. See, for instance, De Long et al. (1990), and Shleifer and Vishny (1997), or Barberis, Shleifer and Vishny (1998) for models of investor sentiment, in which investors' beliefs affect prices and returns.

Note 23. Existing studies distinguish between two fundamental methods of measuring investor sentiment: financial-based measures (or market-wide measures) and survey based measures.

Note 24. See, for instance, Odean (1998) and; Coles, Suay and Woodbury (2000) who report a relationship between advisor fees and premium or discount; Khorana, Wahal and Zenner (2002) exploring the agency conflicts in closed-end funds by examining rights offerings, among others.

Note 25. Also, Lo and Lin (2005), or Kaniel, Saar and Titman (2006) denote investor sentiment as a fundamental factor on the price formation of assets.

Note 26. A survey-based measure was used also by Solt and Statman (1989); Lee, Jiang and Indro (2002), and Ang, Bekaert and Wei (2006).

Note 27. One strand of literature provides evidence that the optimism reflected in generic non-economic proxies of investor mood is positively correlated with the optimistic beliefs about future economic conditions (Conrad, Cornell \& Landsman, 2002; Hirshleifer \& Shumway, 2003; Edmans, Garcia \& Norli, 2007, and Puri \& Robinson, 2007).

Note 28. See, for example, Brennan and Tamarowski (2000) for a history and overview of investor relations. See also Adams, Almeida and Ferreira (2005), and Bertrand and Schoar (2003) for direct evidence that managers have discretion.

Note 29. In their research, ownership concentration is the average ownership of the three largest shareholders in the 10 largest publicly traded companies.

Note 30. We also obtained ownership data from the Worldscope database for the year-end closest to December 31, 2003.

Note 31. Once the dependent variable is a censured variable in that some companies pay dividends whereas do not, the authors predicted a Tobit model following Auerbach and Hasset (2003).

Note 32. According to the Worldscope variable definition, major shareholders represent any individual or company that owns more than the local legal disclosure requirement of the outstanding shares of a company.

Note 33. There are Contestability and dummy variables that take value 1 when the sum of equity stocks held by the two largest shareholders does not exceed $50 \%$ and each one of them has at least $10 \%$ of shares. There are Collusion and dummy variables that take value 0 otherwise.

Note 34. The level of managerial ownership is measured by the fraction of closely held shares to common shares outstanding (number of closely held shares/common shares outstanding * 100).

According to the Worldscope variable definition, closely-held shares represent shares held by insiders: (i) shares held by officers, directors and their immediate families, (ii) shares held in trust, (iii) shares of the company held by any other corporation (except shares held in a fiduciary capacity by banks or other financial institutions), (iv) Shares held by individuals who hold $5 \%$ or more of the outstanding shares, etc. 